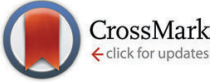

Cite this: New J. Chem., 2016, 40, 6059

Received (in Montpellier, France) 20th January 2016 Accepted 22nd April 2016

DOI: 10.1039/c6nj00202a

www.rsc.org/njc

\title{
Melt-cast materials: combining the advantages of highly nitrated azoles and open-chain nitramines $\uparrow+$
}

\author{
Thomas M. Klapötke, ${ }^{\star}$ Alexander Penger, Carolin Pflüger and Jörg Stierstorfer
}

\begin{abstract}
Numerous efforts to substitute TNT as the melt-cast matrix in explosive charges are ongoing due to its low performance and security issues. In this study the syntheses and full structural as well as spectroscopic characterizations of 2-nitrazapropyl substituted polynitroazoles, as potential melt-cast explosives, are presented. This straightforward method of derivatizing the heterocyclic $\mathrm{N}-\mathrm{H}$ function by introducing a further energetic group improved the stability and energetic properties of the products. X-ray crystallographic measurements were performed for all compounds and afforded insights into structural characteristics such as strong intermolecular interactions. All compounds were characterized in terms of their sensitivities towards impact, friction and electrostatic discharge, and their thermal stabilities. The energetic properties were calculated with the EXPLO5 6.02 program.
\end{abstract}

\section{Introduction}

Melt-cast explosives are used in mortars, grenades and artillery shells and also in civil applications, e.g. for mining and demolition. Nowadays, the melt-cast technology is based on 2,4,6-trinitrotoluene (TNT), 2,4-dinitroanisole (DNAN) and 1,3,3-trinitroazetidine (TNAZ), the structures of which are depicted in Fig. 1. In general, the melt-cast explosives are molten in kettles heated at 80 to $120{ }^{\circ} \mathrm{C}$ with hot water or steam ingredients. ${ }^{1}$ Therefore, an ideal melt-cast explosive or its formulations should have a low melting point $\left(70-120{ }^{\circ} \mathrm{C}\right)$, a sufficient separation of melting and decomposition processes, a low vapor pressure to diminish the inhalation toxicity and a higher density and better performance than the explosives already used. Furthermore, for processing, the melt-cast explosives should show no shrinking or cracking on cooling and no separation from the shell or casing.

The drawbacks of TNT include its low performance $\left(V_{\text {det }}=\right.$ $7300 \mathrm{~m} \mathrm{~s}^{-1}$ ) and the fact that its formulations are weak, brittle and prone to cracking, which increases impact sensitivities and exudation, and leads to dimensional instability with regard to thermal cycling. ${ }^{2}$ DNAN does not show a toxicity drawback,

Department of Chemistry, Ludwig Maximilian University, Munich,

Butenandtstr.5-13,81377 Munich, Germany.E-mail: tmk@cup.uni-muenchen.de

$\dagger$ Parts of this study have been presented at the 14th Seminar on New Trends in Research of Energetic Materials, Pardubice, Czech Republic, April 13-15, 2011 and in the PhD thesis of Alexander Penger.

\# Electronic supplementary information (ESI) available. CCDC 1439310-1439321. For ESI and crystallographic data in CIF or other electronic format see DOI: 10.1039/c6nj00202a<smiles>Cc1c([N+](=O)[O-])cc([N+](=O)[O-])cc1[N+](=O)[O-]</smiles>

TNT<smiles>Cn1c([N+](=O)[O-])nc([N+](=O)[O-])c1[N+](=O)[O-]</smiles>

MeTNI<smiles>COc1ccc([N+](=O)[O-])cc1[N+](=O)[O-]</smiles>

DNAN<smiles>Cn1nc([N+](=O)[O-])c([N+](=O)[O-])c1[N+](=O)[O-]</smiles>

MeTNP<smiles>O=[N+]([O-])N1CC([N+](=O)[O-])([N+](=O)[O-])C1</smiles>

TNAZ<smiles>O=[N+]([O-])c1cn[nH]c1[N+](=O)[O-]</smiles>

Fig. 1 Melt-cast explosives.

which the manufacturing of TNT also possesses, and it is less sensitive than TNT, but its performance is lower. Formulations of TNAZ show issues concerning sensitivities and the ability of the melt-cast process to perform crack-free and tensionfree castings. ${ }^{1}$ Therefore, the development of new melt-cast explosives displaying wide-ranging improvements is still pursued. Polynitrated azoles such as 1-methyl-2,4,5-trinitroimidazole $(\mathrm{MeTNI})^{3}$ and 1-methyl-3,4,5-trinitropyrazole (MeTNP) ${ }^{4}$ as well as 3,4-dinitropyrazole (DNP) ${ }^{5}$ (Fig. 1) show promising properties as replacements for TNT in melt-cast explosives due to their high positive heats of formation, which result from their large numbers of $\mathrm{C}-\mathrm{N}$ and $\mathrm{N}-\mathrm{N}$ bonds as well as from ring/cage strain. ${ }^{6}$ However, the nitro groups lead to increased acidity of the heterocyclic proton, which may result in problems concerning compatibility and storage. A common strategy to avoid the acidity 
and diminish the hygroscopicity is the $\mathrm{N}$-alkylation of the nitro groups by methylation or the introduction of alkyl chains, which leads to better stabilities and compatibilities in formulations of explosive charges. ${ }^{4 a, 7}$

Alkylation using nitramine-containing side groups is an interesting strategy proposed for improving the energetic properties because the nitramine group may take part in intermolecular interactions as the acceptor and donor for hydrogen bonds as well as for dipolar $\mathrm{N} \cdots \mathrm{O}$ and $\mathrm{C}$. . O interactions, which should result in higher densities in comparison to the methylated derivatives. ${ }^{8}$ The linkage of two equal azoles by nucleophilic substitution of 1,3-dichloro-2-nitrazapropane with the corresponding potassium salts of nitrated azoles has been investigated in different research groups, ${ }^{7 c, i, 9}$ based on to studies of Bottaro and Highsmith. ${ }^{10}$ The resulting open-chain nitramines showed high thermal stabilities, high detonation performances and varying sensitivities towards impact and friction but unfortunately they did not melt before decomposition. Therefore, it was concluded that a nitramine function should be introduced without linking the azoles. Preliminary results using 1-chloro-2-nitrazapropane and the in situ double-deprotonated 3-nitro-1,2,4-triazol-5-one as well as various deprotonated tetrazole derivatives (as azole building blocks) revealed promising properties, especially in regard to thermal behavior, melting before decomposing. ${ }^{9,11}$

We now present an extended study of our current work combining the advantages of highly nitrated azoles and nitramines by alkylation of the $\mathrm{N}-\mathrm{H}$ function with 1-chloro-2-nitrazapropane to obtain potential melt-cast explosives.

\section{Results and discussion}

\section{Syntheses}

1-Chloro-2-nitrazapropane was synthesized in two steps as shown in Scheme 1. ${ }^{11}$ After the nitration of 1,3,5-trimethylhexahydro-1,3,5-triazine, the conversion of 2-nitro-2-azapropyl acetate to 1-chloro-2-nitrazapropane was carried out by heating under reflux with thionyl chloride in dichloromethane and with catalytic amounts of acetic acid and sulfuric acid.

The appropriate nitrogen-rich heterocycles were obtained from literature-reported procedures ${ }^{4 a, 10 b, 12}$ and were generally converted to the corresponding potassium salts by using potassium hydroxide. The alkylation of the potassium salts with 1-chloro-2nitrazapropane in aprotic solvents such as acetone or acetonitrile yielded the desired energetic nitramines as depicted in Scheme 2.

In contrast to 1-(3-nitro-1H-1,2,4-triazol-5-on-4-yl)-2-nitrazapropane (1), which was synthesized from the mono potassium salt, the twice alkylated 2 was obtained from the in situ deprotonated free acid 3-nitro-1,2,4-triazol-5-one (NTO) using triethylamine as the base.

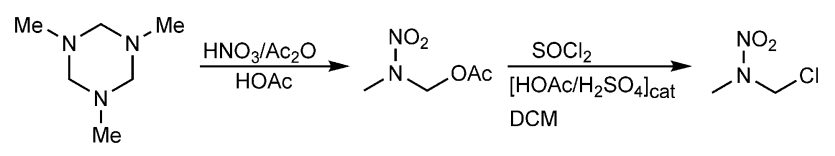

Scheme 1 Synthesis of 1-chloro-2-nitrazapropane starting from 1,3,5trimethyl-hexahydro-1,3,5-triazine.

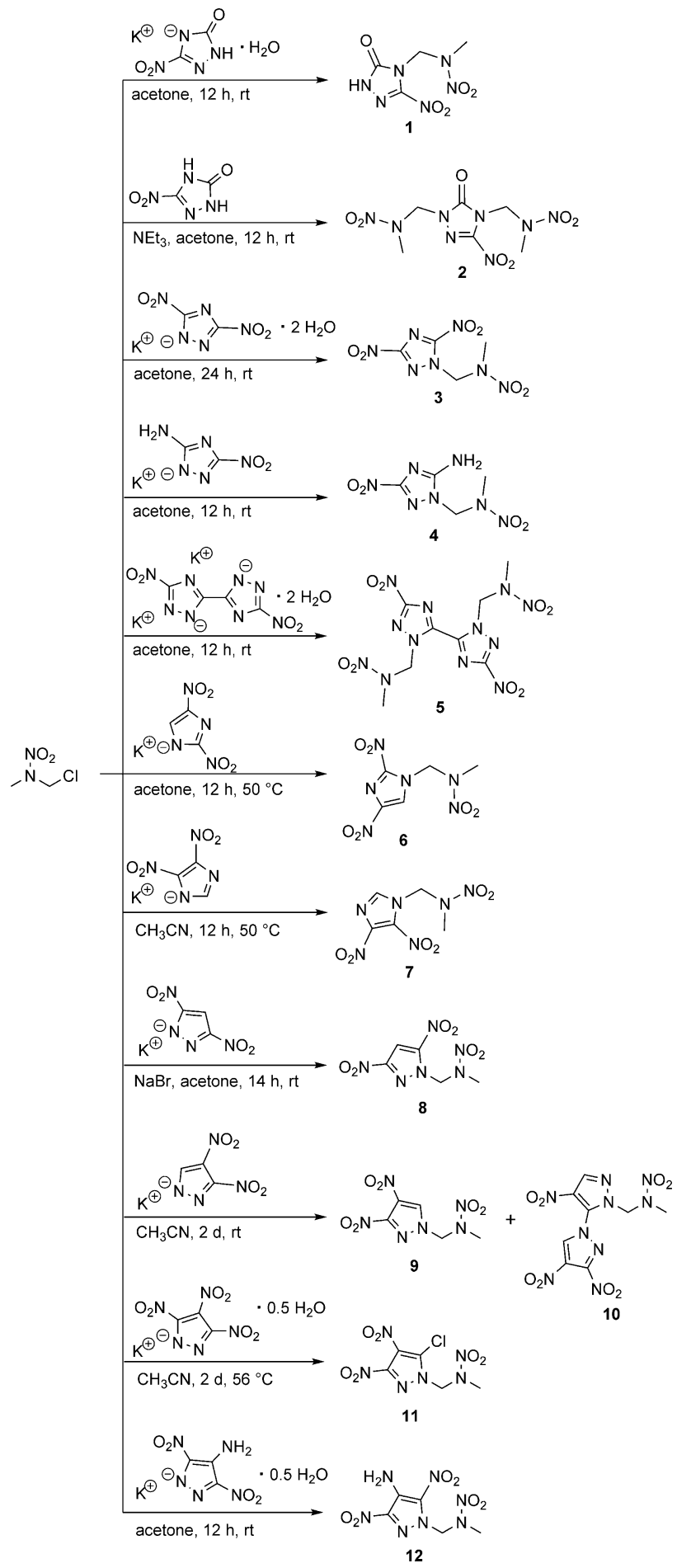

Scheme 2 Syntheses of energetic nitramines starting from 1-chloro-2nitrazapropane.

Various studies concerning the chemical stability of alkylated dinitrotriazoles show elimination of nitrite and formation of NTO derivatives and bistriazolyl systems under basic reaction conditions. ${ }^{13}$ Thus, the alkylation of potassium 3,5-dinitro1,2,4-triazolate was carried out at ambient temperature and in stoichiometric amounts to avoid the elimination of nitrite. The nucleophilic substitution of 1-chloro-2-nitrazapropane with the 
potassium salt of 5-amino-3-nitro-1,2,4-triazole (ANTA) took place at the endocyclic nitrogen atom to yield nitramine $\mathbf{4}$, selectively. Potassium 3,3'-dinitro-5, $5^{\prime}$-bi(1,2,4-triazolate) was alkylated twice at the nitrogen atoms N1/N1' to afford nitramine 5 .

Furthermore, the symmetric and asymmetric dinitroimidazole and symmetric dinitropyrazole derivatives were successfully alkylated to yield nitramines 6,7 , and 8 , respectively. The reaction velocity of the synthesis of $\mathbf{8}$ was optimized by a Finkelstein halogen-exchange using sodium bromide.

Two different substituted nitramines were formed by the alkylation of the potassium 3,4-dinitropyrazolate. The alkylation at $\mathrm{N} 1$ of 3,4-dinitropyrazole afforded the desired nitramine 9. The formation of the other bipyrazolyl based nitramine (10) is caused by the high electrophilicity of the C3 position, which leads to a loss of the nitro group. ${ }^{14}$ The supposed intermediate, the existing 3-chloro-4-nitropyrazolate, ${ }^{15}$ reacted with another equivalent of potassium 3,4-dinitropyrazolate, thereby forming the 3,4,4'-trinitro-1,3'-bipyrazolyl system of nitramine 10. The dependence of the regioselectivity of the alkylation of 3,4-dinitropyrazole on the reaction temperature was studied, revealing that the alkylation at N1 is preferred at low temperatures. The relative ratio of nitramines $\mathbf{9}$ and $\mathbf{1 0}$ was determined by the intensities of the ${ }^{1} \mathrm{H}$ NMR spectra with a reaction time of $24 \mathrm{~h}$ at $25{ }^{\circ} \mathrm{C}(84: 16)$ and $82{ }^{\circ} \mathrm{C}(66: 34)$. The isolated yields are not related to the reported ratio of intensities of the ${ }^{1} \mathrm{H}$ NMR spectra, due to partial decomposition during purification by column chromatography, which also led to very low yields. The same reaction behavior was also observed for the nucleophilic substitution of 1,3-dichloro-2nitrazapropane with potassium 3,4-dinitropyrazolate as reported previously. ${ }^{7 c}$ Prior to the presented synthesis route for bipyrazolyl systems, they were solely available by cine substitutions starting from 1,4-dinitropyrazole derivatives. ${ }^{16}$

The nucleophilic substitution of 1-chloro-2-nitrazapropane with potassium 3,4,5-trinitropyrazolate afforded the 5-chloro3,4-dinitropyrazolate substituted nitramine $\mathbf{1 1}$ due to the specific reactivity of the $\mathrm{C} 5$ position towards nucleophiles. This behavior has already been studied by Dalinger et al. for nucleophilic substitution reactions with methylated 3,4,5-trinitropyrazole. ${ }^{17}$ The reaction of 1-chloro-2-nitrazapropane with potassium 4-amino3,5-dinitropyrazolate in acetone at ambient conditions afforded $\mathbf{1 2}$ in good yield.

\section{Spectroscopy}

Vibrational spectroscopic studies of all synthesized compounds were performed with IR and Raman spectroscopy and the frequencies were assigned according to the literature. ${ }^{18}$ Detailed descriptions are given in the ESI. $\neq$

Compounds 1-12 were characterized by ${ }^{1} \mathrm{H},{ }^{13} \mathrm{C}$, and ${ }^{14} \mathrm{~N}$ NMR spectroscopy in $d_{6}$-acetone. Selected chemical shifts of ${ }^{1} \mathrm{H},{ }^{13} \mathrm{C}\left\{{ }^{1} \mathrm{H}\right\}$, and ${ }^{14} \mathrm{~N}$ resonances of all presented compounds are summarized in Table 1 . The chemical shifts of methylene protons of open-chain nitramines were studied in the 1970s and identified in the range of 5.90-6.10 ppm. ${ }^{19}$ By introducing electron-withdrawing substituents such as nitro groups in the azoles, the resonances of the methylene protons are shifted downfield. This effect is considerable for the 1,2,4-triazole based
Table 1 Assigned ${ }^{1} \mathrm{H},{ }^{13} \mathrm{C}\left\{{ }^{1} \mathrm{H}\right\}$, and ${ }^{14} \mathrm{~N}$ NMR shifts [ppm] of nitramines 1-12 in $d_{6}$-acetone

\begin{tabular}{|c|c|c|c|c|c|c|c|c|c|}
\hline & \multicolumn{3}{|c|}{${ }^{1} \mathrm{H}$ NMR } & \multicolumn{5}{|l|}{${ }^{13} \mathrm{C}\left\{{ }^{1} \mathrm{H}\right\} \mathrm{NMR}$} & \multirow{2}{*}{$\frac{{ }^{14} \mathrm{~N}}{\mathrm{NO}_{2}}$} \\
\hline & $\mathrm{C}_{\mathrm{ar}}-\mathrm{H}$ & $\mathrm{CH}_{2}$ & $\mathrm{CH}_{3}$ & $\mathrm{C}-\mathrm{NO}_{2}$ & $\mathrm{C}-\mathrm{H}$ & $\mathrm{C}_{\mathrm{q}}$ & $\mathrm{CH}_{2}$ & $\mathrm{CH}_{3}$ & \\
\hline 1 & - & 6.02 & 3.57 & 146.2 & - & 152.8 & 58.0 & 39.6 & $\begin{array}{l}-30 \\
-34\end{array}$ \\
\hline 2 & - & $\begin{array}{l}6.03 \\
5.90\end{array}$ & $\begin{array}{l}3.57 \\
3.50\end{array}$ & 145.3 & - & 151.8 & $\begin{array}{l}60.3 \\
58.4\end{array}$ & $\begin{array}{l}39.8 \\
38.3\end{array}$ & $\begin{array}{l}-31 \\
-34\end{array}$ \\
\hline 3 & - & 6.81 & 3.65 & $\begin{array}{l}158.0 \\
151.2\end{array}$ & - & - & 67.0 & 39.0 & $\begin{array}{l}-32 \\
-37\end{array}$ \\
\hline 4 & - & 6.11 & 3.60 & n.o. ${ }^{a}$ & - & 156.9 & 61.6 & 38.5 & $\begin{array}{l}-21 \\
-25\end{array}$ \\
\hline 5 & - & 6.84 & 3.68 & n.o. ${ }^{a}$ & - & 143.7 & 65.4 & 39.1 & -26 \\
\hline 6 & 8.70 & 6.55 & 3.70 & 143.0 & 125.5 & - & 65.3 & 39.8 & $\begin{array}{l}-23 \\
-30 \\
-32\end{array}$ \\
\hline 7 & 8.28 & 6.43 & 3.66 & $\begin{array}{l}142.3 \\
129.6\end{array}$ & 138.0 & - & 62.9 & 39.6 & $\begin{array}{l}-24 \\
-30 \\
-34\end{array}$ \\
\hline 8 & 7.91 & 6.72 & 3.64 & $\begin{array}{l}154.1 \\
147.7\end{array}$ & 103.5 & - & 67.9 & 39.9 & $\begin{array}{l}-25 \\
-30\end{array}$ \\
\hline 9 & 9.03 & 6.33 & 3.63 & $\begin{array}{l}148.4 \\
126.9\end{array}$ & 134.0 & - & 66.9 & 38.8 & $\begin{array}{l}-28 \\
-31\end{array}$ \\
\hline 10 & $\begin{array}{l}9.50 \\
8.56\end{array}$ & 6.33 & 3.59 & $\begin{array}{l}150.1 \\
129.7 \\
128.2\end{array}$ & $\begin{array}{l}138.2 \\
137.0\end{array}$ & 132.0 & 63.9 & 39.0 & $\begin{array}{l}-20 \\
-25 \\
-26\end{array}$ \\
\hline 11 & - & 6.42 & 3.66 & $\begin{array}{l}148.4 \\
123.9\end{array}$ & - & 130.0 & 64.4 & 39.0 & $\begin{array}{l}-28 \\
-31\end{array}$ \\
\hline 12 & - & 6.64 & 3.59 & 130.5-130.4 & - & $130.5-130.4$ & 67.3 & 38.8 & $\begin{array}{l}-18 \\
-23 \\
-26\end{array}$ \\
\hline
\end{tabular}

${ }^{a}$ Due to the low solubility in organic solvents, some carbon signals could not be observed, although the measurements were performed with elongated pulse delays.

nitramines 3 and 5 with resonances at $6.81 \mathrm{ppm}$ and $6.84 \mathrm{ppm}$, respectively. The resonance signals of methyl protons are in the range of $3.50 \mathrm{ppm}$ to $3.70 \mathrm{ppm}$. The $\mathrm{CH}$ resonances of the imidazolyl and pyrazolyl substituents show the characteristic downfield shifts of aromatic protons of nitrogen-rich heterocycles.

The carbon resonances of the $\mathrm{C}-\mathrm{NO}_{2}$ functions are observed as small, broadened signals because of their coupling to the nitrogen cores of the nitro groups. The chemical shifts of the ${ }^{13} \mathrm{C}$ methylene resonances are in the range of $58.0 \mathrm{ppm}$ to $67.0 \mathrm{ppm}$ and the methyl resonances are found in the range from $38.3 \mathrm{ppm}$ to 39.9 ppm.

The resonance signals of the aromatic $\mathrm{C}-\mathrm{NO}_{2}$ and the $\mathrm{N}-\mathrm{NO}_{2}$ nitro group nitrogens are observed in the ${ }^{14} \mathrm{~N}$ NMR from $-18 \mathrm{ppm}$ to $-37 \mathrm{ppm}$. An unambiguous assignment of these signals is difficult because of their similar shifts.

Two-dimensional NMR spectra (HMBC) of $\mathbf{1 0}$ were recorded for an unambiguous assignment of the protons and carbon atoms of the 3,4,4'-trinitro-1,3'-bipyrazole system (Fig. S1, ESI $)$. The assignment is given in Fig. 2. The $\mathrm{C}-\mathrm{H}$ resonance (no. 3) of the nitramine alkylated pyrazole ring is shifted upfield in comparison to the $\mathrm{C}-\mathrm{H}$ resonance of $\mathbf{9}$, whereas $\mathrm{C}-\mathrm{H}$ resonance no. 6 is shifted downfield, because of the neighboring electron-withdrawing substituted pyrazolyl substituent. The methyl and methylene proton resonances of $\mathbf{1 0}$ are in the same range as the ones of $\mathbf{9}$. Additionally, the assignment of the carbon atoms is given in Fig. 2. 


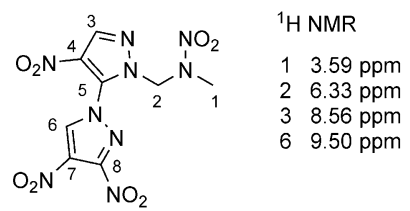$$
10
$$

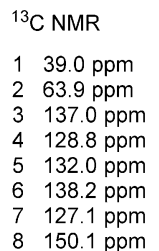

Fig. 2 Assigned ${ }^{1} \mathrm{H}$ and ${ }^{13} \mathrm{C}\left\{{ }^{1} \mathrm{H}\right\}$ NMR resonances of 10 in $d_{6}$-acetone.

\section{Crystal structures}

All presented compounds were also characterized by lowtemperature single-crystal X-ray diffraction. Their molecular structures are depicted in Fig. 3. Selected data and parameters of the measurements and refinements are summarized in Tables S13 to S15 in the ESI.

Nitramine 1 crystallizes from acetone/dichloromethane in the monoclinic space group $P 2{ }_{1}$ with two formula units per unit cell and a density of $1.721 \mathrm{~g} \mathrm{~cm}^{-3}$ at $173 \mathrm{~K}$. Its unit cell is shown in Fig. 4. The twice alkylated nitramine 2 crystallizes as its nitric acid adduct from diluted nitric acid in the monoclinic space group $P 2_{1}$. The $\mathrm{N}-\mathrm{N}$ bond lengths of the nitramine groups of 1 and $2(1.34 \AA)$ are shorter than the $\mathrm{N}-\mathrm{N}$ bond length in the triazolone rings $(1.37 \AA)$. In comparison to the $\mathrm{C}-\mathrm{O}$ bond length of $\gamma$-lactam systems $(1.235 \AA),{ }^{20}$ the $\mathrm{C}-\mathrm{O}$ bond length of nitramine $1(1.214(3) \AA)$ is shorter, whereas the corresponding bond length of 2 is in the same range $(1.230(3) \AA)$. The $\mathrm{C}-\mathrm{N}$ bond length to the nitro group is 1.457(3) $\AA$ and, compared to the $\mathrm{C}-\mathrm{N}$ bond lengths of the triazolone ring (1.293(3)-1.400(3) $\AA$ ), is considerably elongated. The significant differences in the bond lengths are evidence for the localization of the double bond character. In comparison to $\beta-\mathrm{NTO}^{21}$ the $\mathrm{C} 2-\mathrm{N} 2$ bond length (1.293(3) $\AA$ ) is the shortest one, whereas the alkylation leads to an elongated C1-N3 bond length of 1.400(3) ̊ instead of 1.378(2) $\AA^{21}$

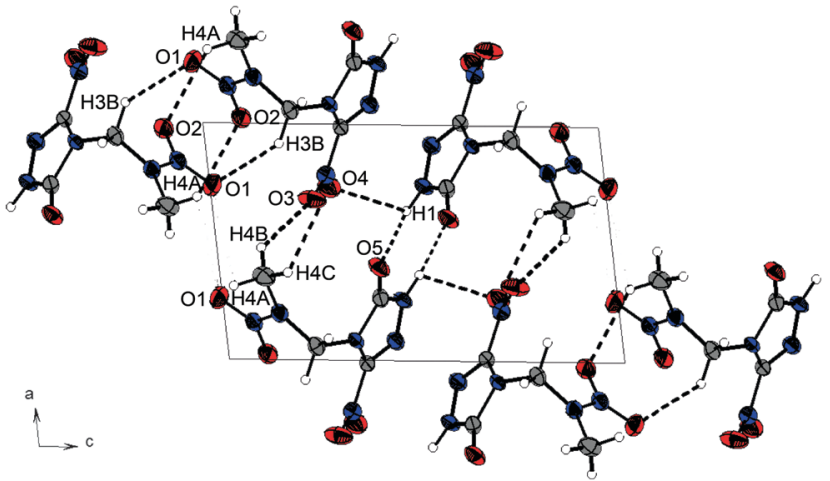

Fig. 4 Unit cell of 1-(3-nitro-1H-1,2,4-triazol-5-on-4-yl)-2-nitrazapropane (1) along the $b$ axis. Thermal ellipsoids are drawn at the 50\% probability level. Selected hydrogen bonds are shown as black dotted lines.

The $\mathrm{C}-\mathrm{NO}_{2}$ function is twisted out of the triazole plane by $20.4^{\circ}$, in contrast to the almost planar structure in NTO. This twisting enables various intermolecular interactions within the crystal structure of 1 . Due to the high acidity of the protons of the 2-nitrazapropyl substituent, non-classical $\mathrm{C}-\mathrm{H} \cdots \mathrm{O}$ and $\mathrm{C}-\mathrm{H} \cdots \mathrm{N}$ hydrogen bonds are formed. Furthermore, high-grade directed dipolar $\mathrm{N} \cdots \mathrm{O}$ and $\mathrm{C} \cdots \mathrm{O}$ interactions are observed in the range from 2.869-2.970 A. These dipolar interactions of $\mathrm{O} 2$ to the $\mathrm{C} 2-\mathrm{N} 4$ bond are supported by the twisting of the $\mathrm{C}-\mathrm{NO}_{2}$ group. The interactions are summarized in Table S1 (ESI $\$$ ). The layer-like packing of $\mathbf{1}$ is formed by an intermolecular hydrogen bond of the acidic $\mathrm{N}-\mathrm{H}$ function and the oxygen of the $\gamma$-lactam system. The layers are connected by weak non-classical hydrogen bonds between the terminal methyl group and the nitro groups, whereas the non-classical hydrogen bond $\mathrm{C} 3-\mathrm{H} 3 \mathrm{~A} \cdots \mathrm{N} 2$ is found within one layer. The dipolar $\mathrm{N} 6 \cdots \mathrm{O} 2$ interaction of $2.970 \AA$ is observed in between the layers.
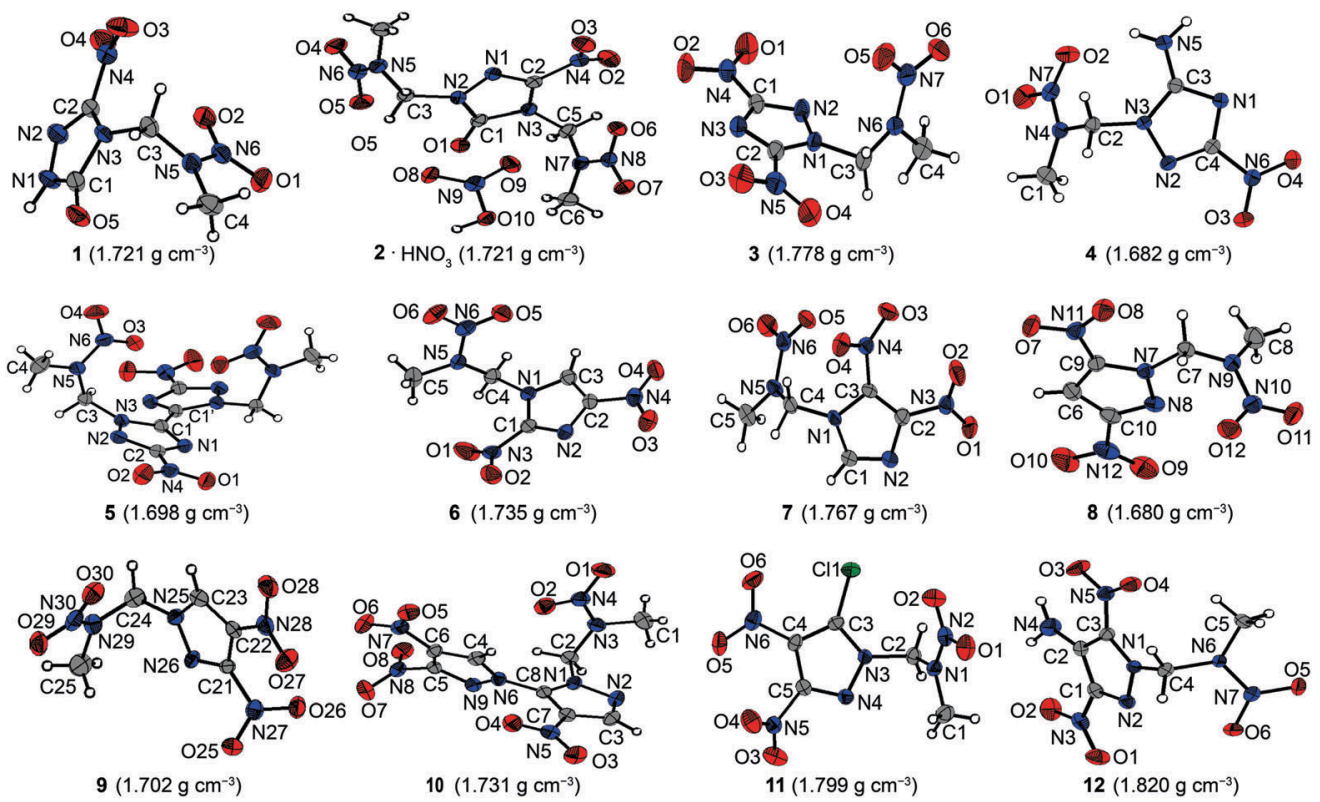

Fig. 3 Molecular structures of nitramines 1-12 presented herein. 
Similar interactions are observed in the crystal structure of nitramine 2 as listed in Table S2 (ESI ).

The crystal structures of the other 1,2,4-triazole based nitramines 3-5 are supported by several non-classical hydrogen bonds and additionally by either classical hydrogen bonds (4) or various dipolar interactions (nitramines $\mathbf{3}$ and 5) as summarized in Tables S3 to S5 (ESI $\ddagger$ ). The structure of nitramine 5 shows $C_{2}$ symmetry perpendicular to the $\mathrm{C} 1-\mathrm{C} 1^{\mathrm{i}}$ axis and its triazole rings are twisted by $26.1(1)^{\circ}$. Its crystal structure is depicted in Fig. S8 (ESI $\$$ ). The molecules of one layer are connected by a dipolar $\mathrm{C} \cdots \mathrm{O}$

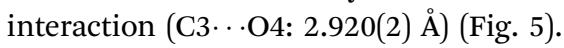

The 4,5-dinitroimidazolyl based nitramine 7 crystallizes with a higher crystal density of $1.767 \mathrm{~g} \mathrm{~cm}^{-3}$ than that of the 2,4-dinitroimidazole based $6\left(1.735 \mathrm{~g} \mathrm{~cm}^{-3}\right)$ at $173 \mathrm{~K}$. Furthermore, a greater extent of non-classical hydrogen bonding and dipolar interactions is observed within the crystal structure of 7 than in that of 6 (Tables S6 and S7, ESI $\ddagger$ ). The crystal structures of the two dinitropyrazolyl based nitramines $\mathbf{8}$ and $\mathbf{9}$ are supported by various non-classical hydrogen bonds, and dipolar $\mathrm{N} \cdots \mathrm{O}$ and C. . O interactions with distances below the sum of the corresponding van der Waals radii (Tables S8 and S9, ESI $\ddagger$ ).

1-(3,4,4'-Trinitro-1,3'-bipyrazol-2'-yl)-2-nitrazapropane (10) crystallizes from dichloromethane in the triclinic space group $P \overline{1}$ with two formula units per unit cell and a crystal density of $1.731 \mathrm{~g} \mathrm{~cm}^{-3}$ at $173 \mathrm{~K}$. The molecular structure of 10 is depicted in Fig. 6 . The pyrazole rings are twisted by $55.86(6)^{\circ}$. The almost perpendicular twists of the nitro groups N7 and N8 are caused by the steric repulsion of the neighboring nitro group, which thereby takes part in intra- and intermolecular interactions. The pyrazole N-N bond lengths of 1.367(2) A and 1.379(2) A are elongated in comparison to the nitramine $\mathrm{N}-\mathrm{N}$ bond length of 1.358(2) A. The alignment of 10 within the crystal structure is formed by non-classical hydrogen bonds. The $\mathrm{C}-\mathrm{H}$ functions of the bipyrazolyl system and the methylene protons interact with the nitro groups and the nitrogen atoms of the bipyrazole due to their high acidity (Table S10, ESI $\ddagger$ ). In addition to the non-classical hydrogen bonds, dipolar high-grade directed $\mathrm{N} \cdots \mathrm{O}$ and $\mathrm{C} \cdots \mathrm{O}$ interactions of oxygen $\mathrm{O} 8$ are observed,

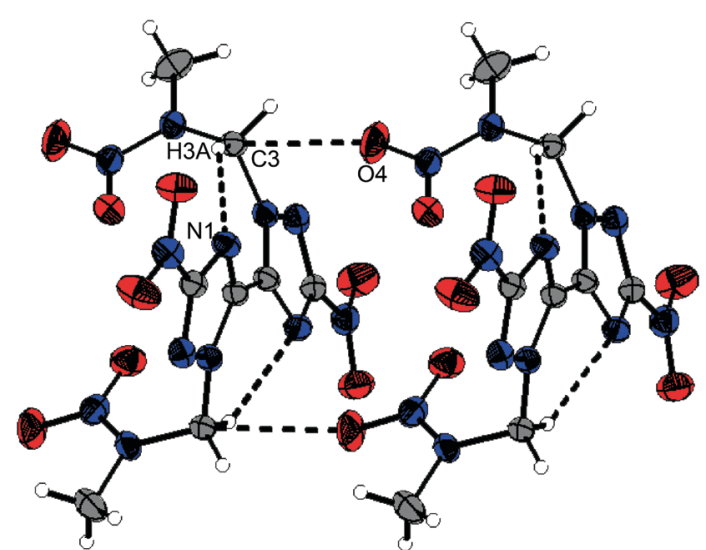

Fig. 5 Selected structure showing dipolar intermolecular C...O interactions and non-classical hydrogen bonds as black dotted lines within the crystal structure of $\mathbf{5}$.

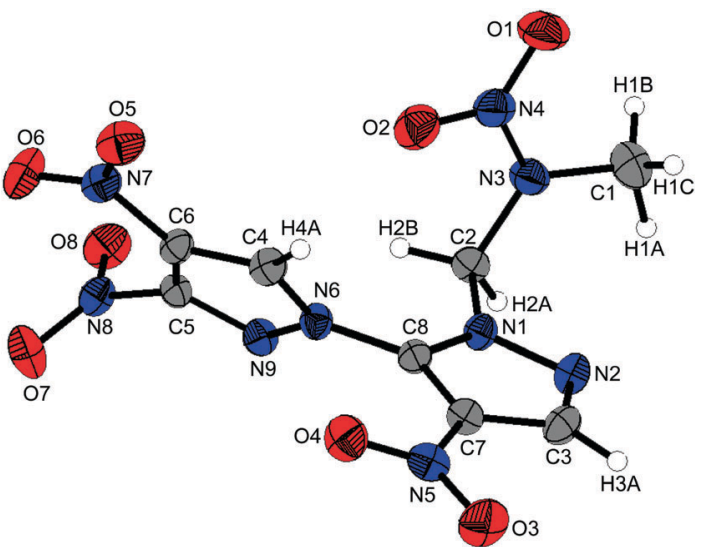

Fig. 6 Molecular structure of 1-(3,4,4'-trinitro-1,3'-bipyrazol-2'-yl)-2nitrazapropane (10). Thermal ellipsoids are drawn at the 50\% probability level.

which are shorter than the corresponding sum of the van der Waals radii. $^{22}$

The neighboring nitro groups of nitramine $\mathbf{1 1}$ are less twisted than those of $\mathbf{1 0}$. The oxygen atoms of the nitro group $\mathrm{N} 6$ as well as the nitramine group are involved in non-classical hydrogen bonds and additionally dipolar interactions are observed (Table S11, ESI $\ddagger$ ).

1-(4-Amino-3,5-dinitropyrazol-1-yl)-2-nitrazapropane (12) crystallizes from acetonitrile/dichloromethane in the monoclinic space group $P 2_{1} / c$ with four formula units per unit cell. The bond lengths and angles in the pyrazole ring are similar to the corresponding ones in the nitramine alkylated ring of the bipyrazolyl system 10. In contrast to the crystal structure of 1-chloro-2-nitrazapropane, ${ }^{23}$ the nitramine nitro group is nonplanar with the C4-C5-N7 plane, but twisted out of the plane by $5.9(1)^{\circ}$. The pyrazolyl ring is turned out of the CNC-plane by $58.11(5)^{\circ}$. Due to the spatial arrangement of the nitramine group, various intramolecular non-classical hydrogen bonds and electrostatic interactions are formed, involving the methyl and methylene groups as donors and the nitramine nitro group as well as the $\mathrm{O} 4$ of the C-bonded nitro group as acceptors (Fig. 7). These and further selected interactions are listed in Table 2. The amino group is twisted out of the pyrazole ring by $3.65(3)^{\circ}$, whereas the nitro groups are almost in plane with a twist of less than $0.5^{\circ}$. These twists enable two intramolecular classical hydrogen bonds of 2.1781(16) $\AA$ and 2.2521(17) A. Furthermore, intramolecular dipolar $\mathrm{N} \cdots \mathrm{O}$ and $\mathrm{C} \cdots \mathrm{O}$ interactions considerably below the sum of the van der Waals radii are observed. The unit cell and crystal structure are shown in Fig. S16 (ESI $\ddagger$ ). The crystal structure consists of two different layers, which are opposed and staggered to each other. The layers are connected by a large number of non-classical and classical hydrogen bonds with a range from 2.40-2.60 A. Remarkably, there is a very uncommon four-center bond, which is formed by proton $\mathrm{H} 1$ of the amino group interacting intermolecularly with oxygen atoms $\mathrm{O} 3$ and $\mathrm{O} 2$ and with another O2. In addition to the intermolecular hydrogen bonds, an intermolecular dipolar C. . O interaction between C3 and O1 


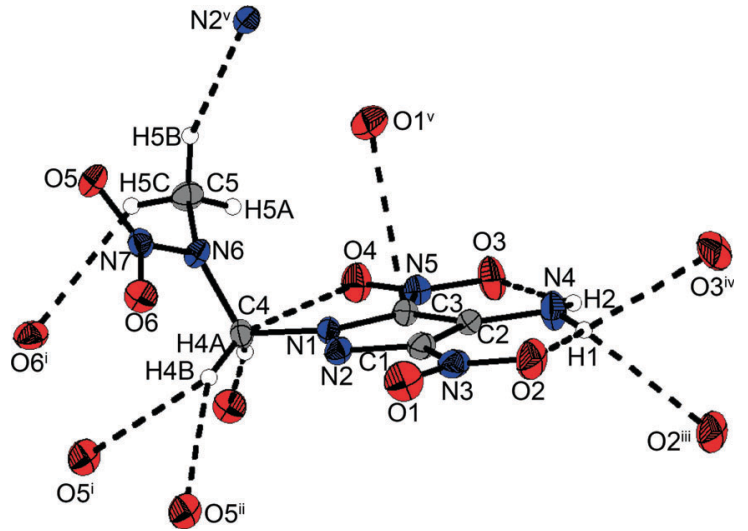

Fig. 7 Selected hydrogen bonds within the crystal structure of $\mathbf{1 2}$ including a four-center hydrogen bond formed by proton $\mathrm{H} 1$ with two different oxygen atoms $\mathrm{O} 2$, and oxygen $\mathrm{O} 3$.

Table 2 Selected interactions within the crystal structure of $\mathbf{1 2}$

\begin{tabular}{|c|c|c|c|c|}
\hline $\mathrm{D}-\mathrm{H} \cdots \mathrm{A}$ & $\mathrm{D}-\mathrm{H}[\AA]$ & $\mathrm{H} \cdots \mathrm{A}[\mathrm{A}]$ & $\mathrm{D} \cdots \mathrm{A}[\mathrm{A}]$ & $\angle \mathrm{DHA}\left[{ }^{\circ}\right]$ \\
\hline C5-H5A $\cdots$ O4 & $0.981(2)$ & $2.3212(16)$ & $3.174(3)$ & $144.94(13)$ \\
\hline $\mathrm{N} 4-\mathrm{H} 2 \cdots \mathrm{O} 3$ & $0.8954(7)$ & $2.1781(16)$ & $2.7687(18)$ & $122.93(6)$ \\
\hline $\mathrm{N} 4-\mathrm{H} 1 \cdots \mathrm{O} 2$ & $0.8763(7)$ & $2.2521(17)$ & $2.8219(18)$ & $122.54(6)$ \\
\hline C4-H4A $\cdots$ O6 & $0.9902(7)$ & $2.4025(17)$ & $3.3827(18)$ & $170.31(6)$ \\
\hline $\mathrm{N} 4-\mathrm{H} 1 \cdots \mathrm{O} 3^{\text {iv }}$ & $0.8763(7)$ & $2.4858(14)$ & $3.0075(16)$ & $118.79(5)$ \\
\hline $\mathrm{N} 4-\mathrm{H} 1 \cdots \mathrm{O} 2^{\mathrm{iii}}$ & $0.8763(7)$ & $2.5768(17)$ & $3.1444(18)$ & $123.13(6)$ \\
\hline $\mathrm{C} 4-\mathrm{H} 4 \mathrm{~B} \cdots \mathrm{O} 5^{\mathrm{ii}}$ & $0.9904(6)$ & $2.6017(14)$ & $3.5332(16)$ & 156.74(5) \\
\hline $\mathrm{C} 5-\mathrm{H} 5 \mathrm{~B} \cdots \mathrm{N} 2^{\mathrm{v}}$ & $0.980(2)$ & $2.5903(16)$ & $3.479(3)$ & $150.99(13)$ \\
\hline C5-H5C $\cdots$ O6 $^{\mathrm{i}}$ & $0.980(2)$ & $2.5719(14)$ & $3.293(2)$ & $130.43(12)$ \\
\hline $\mathrm{C} 4-\mathrm{H} 4 \mathrm{~B} \cdots \mathrm{O}^{\mathrm{i}}$ & $0.9904(6)$ & $2.5871(15)$ & $3.2073(15)$ & $120.66(5)$ \\
\hline
\end{tabular}

Dipolar interactions $\Sigma$ vdW radii $(\mathrm{N} \cdots \mathrm{O})<3.07 \AA^{22}$

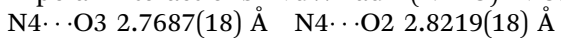

Dipolar interactions $\Sigma$ vdW radii $(\mathrm{C} \cdots \mathrm{O})<3.22 \AA^{22}$

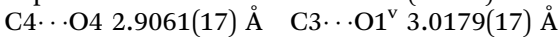

Symmetry codes: (i) $1-x, 0.5+y, 0.5-z$; (ii) $x,-0.5-y, 0.5+z$; (iii) $-x$, $-y, 1-z$; (iv) $-x,-0.5+y, 0.5-z$; (v) $x,-0.5-y,-0.5+z$.

of 3.0179(17) $\AA$ is observed. The high number of intra- and intermolecular interactions leads to the high density of $1.820 \mathrm{~g} \mathrm{~cm}^{-3}$ at $173 \mathrm{~K}$, which is the highest of all the herein presented nitramines.

\section{Thermal stabilities, sensitivities and energetic properties}

The thermal behavior of all the presented compounds was investigated by differential scanning calorimetry (DSC) (Table 3). With the exception of 1-(3-nitro- $1 H$-1,2,4-triazol-5-on-4-yl)-2nitrazapropane (1), all nitramines melt before decomposition. For potential applications as energetic ingredients, a thermal stability above $180{ }^{\circ} \mathrm{C}$ is desired, which is achieved by the majority of the compounds. They show thermal stabilities from $151{ }^{\circ} \mathrm{C}$ to $264{ }^{\circ} \mathrm{C}$.

Especially for melt-cast applications the pyrazole based nitramines 8-11 and $\mathbf{2}$ are of great interest; all of these melt below $140{ }^{\circ} \mathrm{C}$ and reach $80-150{ }^{\circ} \mathrm{C}$ before decomposition. In general, the pyrazole based nitramines 8-12 show higher thermal stabilities than the imidazole based nitramines 6 and 7. The replacement of one nitro group in 1-(3,5-dinitro-1,2,4-triazol-1-yl)-2-nitrazapropane (3) by an amino group (4) leads to an increase in thermal stability of almost $60{ }^{\circ} \mathrm{C}$. The same effect is observed for the thermal stability of the twice alkylated 3-nitro-1,2,4-triazol-5-one 2 in comparison to the mono alkylated 1.

The impact, friction and electrostatic discharge sensitivity tests were carried out for initial safety testing according to BAM methods. ${ }^{24}$ All presented nitramines are sensitive towards friction, with the exception of 1-(4-amino-3,5-dinitropyrazol-1-yl)2-nitrazapropane (12). The impact sensitivities of the 1,2,4-triazolyl based nitramines differ strongly depending on the substituents and vary from sensitive to insensitive. Therefore, the twice alkylated NTO derivative 2 as well as 1-(5-amino-3-nitro-1,2,4triazol-1-yl)-2-nitrazapropane (4) and the bitriazole 5 are insensitive towards impact, whereas 1 and 3 show sensitivities of $10 \mathrm{~J}$ and $7 \mathrm{~J}$. The 2,4-dinitroimidazolyl nitramine 6 is less sensitive than the 4,5-dinitroimidazolyl nitramine 7; they show impact sensitivities of $38 \mathrm{~J}$ and $25 \mathrm{~J}$, respectively. The pyrazolyl based derivatives are insensitive towards impact, with the exception of 1-(3,5-dinitropyrazol-1-yl)-2-nitrazapropane (8) (19 J). The electrostatic sensitivities of all presented compounds are within the range of $0.25-0.6 \mathrm{~J}$ and so are greater than the values $(0.005-0.02 \mathrm{~J})$ that the human body can release. ${ }^{25}$ In comparison to TNT, the synthesized nitramines mainly show lower impact sensitivities but increased sensitivities towards friction. In the first instance, the performance characteristics of new energetic materials are calculated to evaluate their utility for possible applications. The detonation parameters of all presented nitramines were calculated using the EXPLO5 (version 6.02) computer code. ${ }^{26}$ The calculations were performed using the maximum densities at $25{ }^{\circ} \mathrm{C}$ and the calculated enthalpies of formation. Enthalpies of formation were calculated using the atomization method, with $\mathrm{CBS}-4 \mathrm{M}^{27}$ based electronic enthalpies computed with the Gaussian 09 A.02 program. ${ }^{28}$ Gas phase enthalpies were transformed to solid state enthalpies by Trouton's rule, by substracting the corresponding enthalpies of sublimation from the gas-phase enthalpies. ${ }^{29}$ If the compound had no melting point, the decomposition point was used instead to transform the gas phase enthalpy to the solid state enthalpy by Trouton's rule. The crystal densities at low temperature were corrected to the corresponding crystal densities at $298 \mathrm{~K}$ using eqn (1) and the $\alpha_{\mathrm{v}}$ coefficient of volume expansion from the related nitramine $\operatorname{HMX}\left(\alpha_{\mathrm{v}}=1.6 \times 10^{-4} \mathrm{~K}^{30}\right)$.

$$
\rho_{298 \mathrm{~K}}=\rho_{\mathrm{T}} /\left(1+\alpha_{\mathrm{v}}(298-T)\right)
$$

The energetic properties of all presented compounds are summarized in Table 3 . The calculated detonation velocities $\left(V_{\mathrm{det}}\right)$ of all compounds range from $7788 \mathrm{~m} \mathrm{~s}^{-1}$ to $8482 \mathrm{~m} \mathrm{~s}^{-1}$. The detonation pressures $\left(p_{\mathrm{CJ}}\right)$ of the nitramines at the ChapmanJouguet point are calculated in the range from $235 \mathrm{kbar}$ to 298 kbar. All nitramines show improved detonation performances in comparison to the widely used melt-cast explosives TNT and DNAN.

Most promising for potential applications as TNT replacements in melt-cast formulations are nitramines 2, 6, 8 and 9 with regard to their thermal behavior, sensitivities and performance.

Furthermore, 1-(3,5-dinitro-1,2,4-triazol-1-yl)-2-nitrazaprop-ane (3) and 1-(4-amino-3,5-dinitropyrazol-1-yl)-2-nitrazaprop-ane (12) 
Table 3 Physical and energetic properties of nitramines 1-12 in comparison to TNT, DNAN and PETN

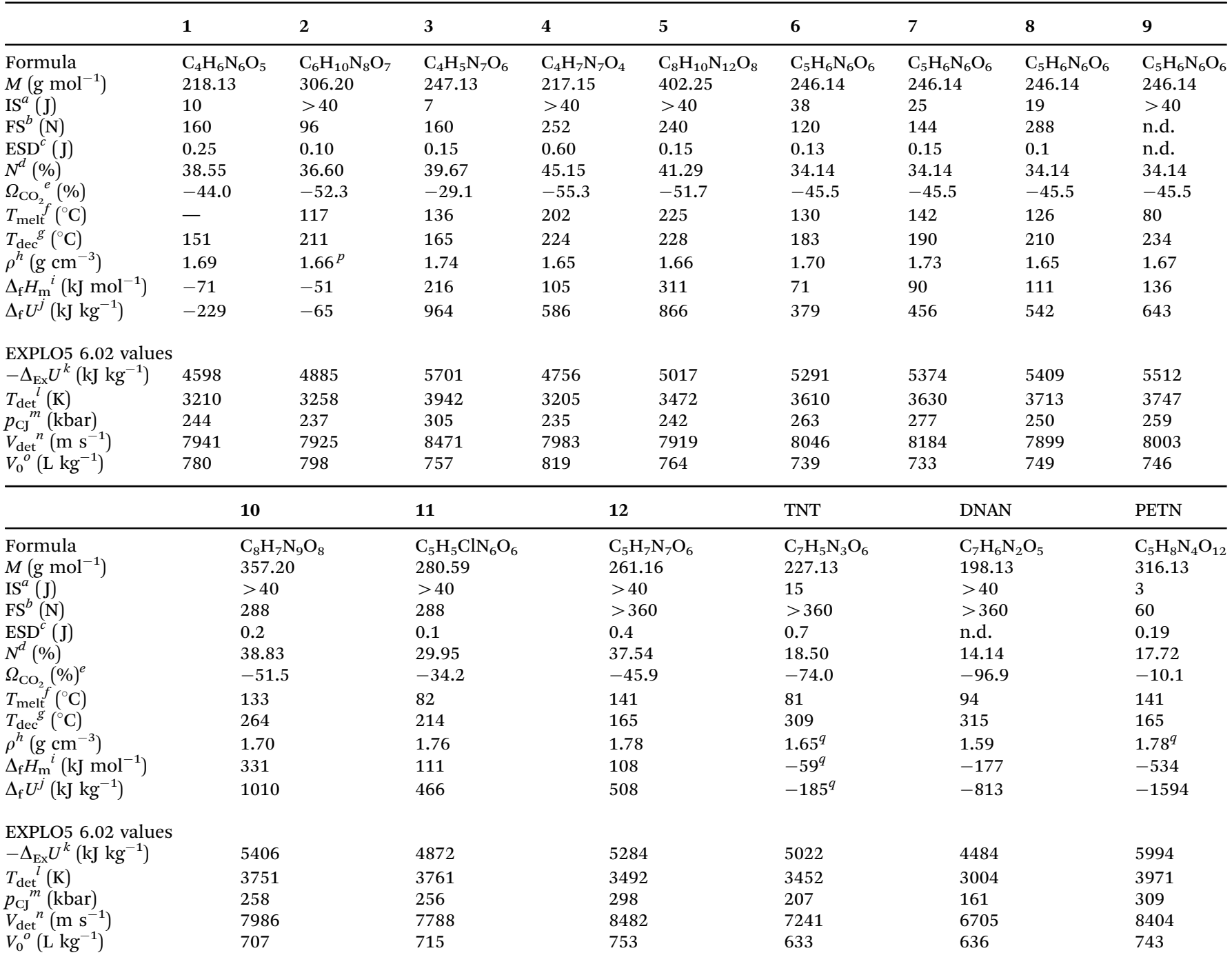

${ }^{a}$ Impact sensitivity (BAM drophammer 1 of 6$) .{ }^{b}$ Friction sensitivity (BAM friction tester 1 of 6$) .{ }^{c}$ Electrostatic discharge (OZM Research). ${ }^{d}$ Nitrogen content. ${ }^{e}$ Oxygen balance $(\Omega=(x \mathrm{O}-2 y \mathrm{C}-0.5 z \mathrm{H}) 1600 / M) .{ }^{f}$ Melting temperature. ${ }^{g}$ Decomposition temperature. ${ }^{h}$ Density at ambient temperature. ${ }^{i}$ Calculated enthalpy of formation. ${ }^{j}$ Calculated energy of formation. ${ }^{k}$ Energy of explosion. ${ }^{l}$ Detonation temperature. ${ }^{m}$ Detonation pressure. ${ }^{n}$ Detonation velocity. ${ }^{o}$ Volume of detonation gases. ${ }^{p}$ Density measured with a He pycnometer. ${ }^{q}$ Values obtained from the EXPLO5 database.

could be of potential use for energetic applications, since they show performances comparable to that of pentaerythritol tetranitrate (PETN) while possessing lower sensitivities.

\section{Conclusions}

Nucleophilic substitution of 1-chloro-2-nitrazapropane with nitro-substituted azoles afforded various open-chain nitramines, as reported herein. The alkylation of 3,4-dinitro-pyrazole yielded not only the desired nitramine 9 but also the alkylated bipyrazolyl system 10. Prior to this reaction, bipyrazolyl systems were solely obtained by cine substitutions.

The crystal structures of all compounds were determined by low-temperature single-crystal X-ray diffraction and deliver insight into structural characteristics. A plurality of hydrogen bonds and dipolar $\mathrm{C} \cdots \mathrm{O}$ and $\mathrm{N} \cdots \mathrm{O}$ interactions is observed within each crystal structure, which leads to higher densities compared to the known crystal structures of the methylated parent compounds. In particular, within the crystal structure of 1-(4-amino-3,5-dinitropyrazol-1-yl)-2-nitrazapropane (12), an abundance of intra- and intermolecular interactions is observed, which leads to the highest density $\left(1.82 \mathrm{~g} \mathrm{~cm}^{-3}\right)$ of the herein presented nitramines. With the exception of $\mathbf{1}$, all nitramines melt before decomposition. The decomposition temperatures range from 151 to $264{ }^{\circ} \mathrm{C}$. The thermally most stable compound is the bipyrazolyl nitramine 10. Due to the comparatively low melting points of nitramines $\mathbf{2}$ and $\mathbf{8 - 1 1}\left(<135{ }^{\circ} \mathrm{C}\right)$ and their considerably higher decomposition points, they are promising as potential melt-cast explosives.

Sensitivities towards impact, friction and electrostatic discharge were investigated by BAM methods. Compounds $\mathbf{1 ,} \mathbf{3}$ and 6-8 are 
found to be sensitive towards impact, while the others are insensitive. All compounds are sensitive towards friction with values between $96 \mathrm{~N}$ and $288 \mathrm{~N}$, with the exception of $12(>360 \mathrm{~N}$, insensitive); these sensitivities are mainly in the range of RDX and PETN or even improved. The nitramines show calculated performances with detonation velocities in the range from 7788-8482 $\mathrm{m} \mathrm{s}^{-1}$ and detonation pressures between 235-305 kbar. Nitramines 3 and 12 exhibit performances comparable to PETN, accompanied by lower sensitivities towards impact and friction. However, their thermal stabilities are lower than $180{ }^{\circ} \mathrm{C}$. Therefore, the most promising compounds for potential applications as energetic materials with regard to their sensitivities and performances are the imidazolyl based nitramines 6 and 7. The most promising potential TNT replacements are nitramines $\mathbf{2 , 6}$ and 8, taking into account their syntheses, sensitivities, energetic performances and, especially, their thermal behaviors.

\section{Experimental section}

\section{Caution}

All materials prepared are energetic compounds with sensitivities to various stimuli. While we encountered no issues in the handling of these materials, proper protective measures (face shield, ear protection, body armor, Kevlar gloves and earthed equipment) should be used at all times.

\section{General methods}

All reagents and solvents were used as received (Sigma-Aldrich, Fluka, Acros Organics), if not stated otherwise. 5-Nitro-2,4dihydro-1,2,4-triazol-3-one, ${ }^{12 k}$ 3,5-dinitro-1,2,4-tri-azole, ${ }^{10 b}$ 5-amino3-nitro-1,2,4-triazole, ${ }^{12 a} \quad 3,3^{\prime}$-dinitro-5, $5^{\prime}$-bi(1,2,4-triazole) ${ }^{12 j}$ 4,5-dinitroimidazole, ${ }^{12 c}$ 2,4-dinitroimid-azole, ${ }^{12 d}$ 3,5-dinitropyrazole, $^{12 e, f}$ 3,4-dinitropyrazole, ${ }^{12 f, g}$ 3,4,5-trinitropyrazole, ${ }^{4 a}$ and 4-amino-3,5-dinitropyrazole ${ }^{12 b}$ were prepared according to literature procedures. Melting and decomposition points were measured with a Linseis PT10 DSC using heating rates of $5{ }^{\circ} \mathrm{C} \mathrm{min}{ }^{-1} \cdot{ }^{1} \mathrm{H},{ }^{13} \mathrm{C}\left\{{ }^{1} \mathrm{H}\right\}$ and ${ }^{14} \mathrm{~N}$ NMR spectra were measured with a JEOL EX 400 or a JEOL Eclipse 400 instrument at ambient temperature. Chemical shifts are quoted in parts per million relative to TMS $\left({ }^{1} \mathrm{H},{ }^{13} \mathrm{C}\right)$ or nitromethane $\left({ }^{14} \mathrm{~N}\right)$. The solvent used was $d_{6}$-acetone unless otherwise stated. The solvent residue signal was used as the locking signal for ${ }^{1} \mathrm{H}$ and ${ }^{13} \mathrm{C}$ NMR. Infrared spectra were measured with a PerkinElmer BX FT-IR spectrometer on a Smiths DuraSamplIR II diamond ATR unit at ambient temperature. The following abbreviations are used to characterize the relative signal intensities: vs (very strong), s (strong), m (medium), w (weak), vw (very weak) and br (broad). Raman spectra were recorded on a Bruker BAN II using a Nd:YAG laser $(\lambda=1064 \mathrm{~nm})$ with a laser output of $300 \mathrm{~mW}$. The vibrational spectroscopy data is given in the ESI. + Lowresolution mass spectra were recorded on a JEOL MStation JMS 700. Elemental analyses were performed on a Vario EL and a Vario Micro from Elementar Company. Sensitivity data were determined using a BAM drophammer and a BAM friction tester. The electrostatic sensitivity tests were carried out using an Electric Spark Tester ESD 2010 EN from OZM Research. Single-crystal X-ray diffraction studies were performed on an Oxford Diffraction XCalibur 3 diffractometer with a Kappa CCD detector using monochromatic molybdenum $\mathrm{K}_{\alpha}$ radiation $(\lambda=0.71073 \AA)$. The data collection was realized by using CrysAlisPro software. ${ }^{31}$ The structures were solved with SIR-92 implemented in the program package WinGX ${ }^{32}$ and finally checked using Platon. ${ }^{33}$

The EXPLO5 program is based on the steady-state model of equilibrium and uses the Becker-Kistiakowsky-Wilson equation of state (BKW EOS) for gaseous detonation products and the CowanFickett EOS for solid carbon. ${ }^{34}$ It is designed to enable the calculation of detonation parameters at the Chapman-Jouguet point.

\section{Syntheses}

1-(3-Nitro-1H-1,2,4-triazol-5-on-4-yl)-2-nitrazapropane (1). To a solution of potassium 3-nitro-1,2,4-triazolat-5-one mono-hydrate $(2.86 \mathrm{~g}, 15.36 \mathrm{mmol})$ in acetone $(30 \mathrm{~mL})$ was added dropwise 1-chloro-2-nitrazapropane (1.91 g, $15.36 \mathrm{mmol})$ dissolved in acetone $(10 \mathrm{~mL})$ by stirring at ambient temperature. The reaction mixture was stirred overnight and the inorganic solid was filtered off. The organic layer was concentrated in vacuo to afford a pale yellow solid. The crude product was washed with ethanol $(10 \mathrm{~mL})$ and hot water $(10 \mathrm{~mL})$ to yield 1 (437 $\mathrm{mg}, 2.00 \mathrm{mmol}, 13 \%)$ as a colorless solid.

DSC: $T_{\mathrm{dec}}=151{ }^{\circ} \mathrm{C} . \mathrm{EA}\left(\mathrm{C}_{4} \mathrm{H}_{6} \mathrm{~N}_{6} \mathrm{O}_{5}, 218.13 \mathrm{~g} \mathrm{~mol}^{-1}\right)$ : calcd C 22.03, H 2.77, N 38.55\%; found $\mathrm{C} 23.44, \mathrm{H} 2.85, \mathrm{~N} 36.08 \%$. ${ }^{1} \mathrm{H}$ NMR (400 MHz): $\delta 12.00(\mathrm{~s}, 1 \mathrm{H}, \mathrm{NH}), 6.02\left(\mathrm{~s}, 2 \mathrm{H}, \mathrm{CH}_{2}\right)$, $3.57 \mathrm{ppm}\left(\mathrm{s}, 3 \mathrm{H}, \mathrm{CH}_{3}\right) .{ }^{13} \mathrm{C}\left\{{ }^{1} \mathrm{H}\right\}$ NMR (101 MHz): $\delta 152.8(\mathrm{CO})$, 146.2 (br, $\left.C \mathrm{NO}_{2}\right), 58.0\left(\mathrm{CH}_{2}\right), 39.6 \mathrm{ppm}\left(\mathrm{CH}_{3}\right) .{ }^{14} \mathrm{~N}\left\{{ }^{1} \mathrm{H}\right\} \mathrm{NMR}$ $(29 \mathrm{MHz}): \delta-30\left(\mathrm{NO}_{2}\right),-34 \mathrm{ppm}\left(\mathrm{NO}_{2}\right) . \mathrm{MS}\left(\mathrm{DCI}^{+}\right): \mathrm{m} / z(\%):$ 219 (16) $\left[\mathrm{M}+\mathrm{H}^{+}\right]$. Sensitivities (grain size: $<100 \mu \mathrm{m}$ ): IS: $10 \mathrm{~J}$; FS: $160 \mathrm{~N}$; ESD: $0.25 \mathrm{~J}$.

2,4-Bis(2-nitrazaprop-1-yl)-3-nitro-1,2,4-triazol-5-one (2). To a solution of 5-nitro-2,4-dihydro-1,2,4-triazol-3-one $(214 \mathrm{mg}$, $1.64 \mathrm{mmol})$ in acetone $(10 \mathrm{~mL})$ was added dropwise a solution of triethylamine $(331 \mathrm{mg}, 3.27 \mathrm{mmol})$ in acetone $(1 \mathrm{~mL})$. After $5 \mathrm{~min}$ of stirring, 1-chloro-2-nitrazapropane (610 mg, $4.90 \mathrm{mmol}$ ) was added. The reaction mixture was stirred overnight at ambient temperature and the formed inorganic solid was filtered off. The organic layer was concentrated in vacuo and the yellow oily crude product was treated with dichloromethane. The resulting solid was washed with diethyl ether and air-dried to afford colorless 2 (166 mg, $0.54 \mathrm{mmol}, 33 \%$ ). DSC: $T_{\text {melt }}=117^{\circ} \mathrm{C}, T_{\text {dec }}=211^{\circ} \mathrm{C}$. EA $\left(\mathrm{C}_{6} \mathrm{H}_{10} \mathrm{~N}_{8} \mathrm{O}_{7}, 306.19 \mathrm{~g} \mathrm{~mol}^{-1}\right)$ : calcd C 23.54, H 3.29, N 36.60\%; found C 23.78, H 3.19, N 35.43\%. ${ }^{1} \mathrm{H}$ NMR (400 MHz): $\delta 6.03$ (s, $\left.2 \mathrm{H}, \mathrm{CH}_{2}\right), 5.90\left(\mathrm{~s}, 2 \mathrm{H}, \mathrm{CH}_{2}\right), 3.57\left(\mathrm{~s}, 3 \mathrm{H}, \mathrm{CH}_{3}\right), 3.50 \mathrm{ppm}(\mathrm{s}, 3 \mathrm{H}$, $\left.\mathrm{CH}_{3}\right) \cdot{ }^{13} \mathrm{C}\left\{{ }^{1} \mathrm{H}\right\}$ NMR (101 MHz): $\delta 151.8(\mathrm{CO}), 145.3\left(\mathrm{br}, \mathrm{CNO}_{2}\right.$ ), $60.3\left(\mathrm{CH}_{2}\right), 58.4\left(\mathrm{CH}_{2}\right), 39.8\left(\mathrm{CH}_{3}\right), 38.3 \mathrm{ppm}\left(\mathrm{CH}_{3}\right) .{ }^{14} \mathrm{~N}\left\{{ }^{1} \mathrm{H}\right\} \mathrm{NMR}$ (29 MHz): $\delta-31\left(\mathrm{NO}_{2}\right),-34 \mathrm{ppm}\left(\mathrm{NO}_{2}\right) . \mathrm{MS}\left(\mathrm{DCI}^{+}\right): \mathrm{m} / z(\%): 307$ (6) $\left[\mathrm{M}+\mathrm{H}^{+}\right]$. Sensitivities (grain size: $<100 \mu \mathrm{m}$ ): IS: $>40$ J; FS: 96 $\mathrm{N}$; ESD: $0.10 \mathrm{~J}$.

1-(3,5-Dinitro-1,2,4-triazol-1-yl)-2-nitrazapropane (3). To a solution of 1-chloro-2-nitrazapropane (400 $\mathrm{mg}, 2.52 \mathrm{mmol}$ ) in acetonitrile $(5 \mathrm{~mL})$ was added potassium 3,5-dinitrotriazolate dihydrate $(744 \mathrm{mg}, 3.19 \mathrm{mmol}$ ). The reaction mixture was stirred for $24 \mathrm{~h}$ at ambient temperature. The formed precipitate 
was filtered off and the organic layer was removed in vacuo. The oily crude product was purified by washing with ethanol (10 mL). After filtration, colorless 3 (494 mg, $2.39 \mathrm{mmol}, 95 \%)$ was obtained. DSC: $T_{\text {melt }}=136{ }^{\circ} \mathrm{C}, T_{\text {dec }}=165{ }^{\circ} \mathrm{C}$. $\mathrm{EA}\left(\mathrm{C}_{4} \mathrm{H}_{5} \mathrm{~N}_{7} \mathrm{O}_{6}\right.$, $\left.247.13 \mathrm{~g} \mathrm{~mol}^{-1}\right)$ : calcd C 19.44, H 2.04, N 39.67\%; found C 19.11, H 1.95, N 38.73\%. ${ }^{1} \mathrm{H}$ NMR (400 MHz): $\delta 6.81$ (s, $2 \mathrm{H}$, $\mathrm{CH}_{2}$ ), $3.65 \mathrm{ppm}\left(\mathrm{s}, 3 \mathrm{H}, \mathrm{CH}_{3}\right) \cdot{ }^{13} \mathrm{C}\left\{{ }^{1} \mathrm{H}\right\} \mathrm{NMR}(101 \mathrm{MHz}): \delta 158.0$ (br, $\left.C \mathrm{NO}_{2}\right), 151.2$ (br, $\left.\mathrm{CNO}_{2}\right), 67.0\left(\mathrm{CH}_{2}\right), 39.0 \mathrm{ppm}\left(\mathrm{CH}_{3}\right)$. ${ }^{14} \mathrm{~N}\left\{{ }^{1} \mathrm{H}\right\}$ NMR $(29 \mathrm{MHz}): \delta-32\left(\mathrm{NO}_{2}\right),-37\left(\mathrm{NO}_{2}\right),-169 \mathrm{ppm}$ (br). MS (DCI $\left.{ }^{+}\right): m / z(\%): 248$ (1) $\left[\mathrm{M}+\mathrm{H}^{+}\right]$. Sensitivities (grain size: $<100 \mu \mathrm{m})$ : IS: 7 J; FS: $160 \mathrm{~N}$; ESD: $0.15 \mathrm{~J}$.

1-(5-Amino-3-nitro-1,2,4-triazol-1-yl)-2-nitrazapropane 1-Chloro-2-nitrazapropane (215 mg, $1.73 \mathrm{mmol}$ ) was dissolved in acetone $(20 \mathrm{~mL})$ and potassium 5-amino-3-nitro-1,2,4-triazolate ( $289 \mathrm{mg}, 1.73 \mathrm{mmol}$ ) was added. The reaction mixture was stirred overnight at ambient temperature. The precipitate was filtered off and the solvent was removed in vacuo to afford an orange solid. It was washed with ethanol $(10 \mathrm{~mL})$ and water $(10 \mathrm{~mL})$. Recrystallization from acetonitrile yielded beige 4 (67 mg, $0.31 \mathrm{mmol}, 18 \%)$. DSC: $T_{\text {melt }}=202{ }^{\circ} \mathrm{C}, T_{\text {dec }}=224{ }^{\circ} \mathrm{C}$. EA $\left(\mathrm{C}_{4} \mathrm{H}_{7} \mathrm{~N}_{7} \mathrm{O}_{4}, 217.14 \mathrm{~g} \mathrm{~mol}^{-1}\right)$ : calcd C 22.12, H 3.25, N 45.15\%; found C 22.65, H 3.14, N 44.52\%. ${ }^{1} \mathrm{H}$ NMR (400 MHz): $\delta 6.58$ (s, $\left.2 \mathrm{H}, \mathrm{NH}_{2}\right), 6.11\left(\mathrm{~s}, 2 \mathrm{H}, \mathrm{CH}_{2}\right), 3.60 \mathrm{ppm}\left(\mathrm{s}, 3 \mathrm{H}, \mathrm{CH}_{3}\right) .{ }^{13} \mathrm{C}\left\{{ }^{1} \mathrm{H}\right\} \mathrm{NMR}$ (101 MHz): $\delta$ 156.9, $61.6\left(\mathrm{CH}_{2}\right), 38.5 \mathrm{ppm}\left(\mathrm{CH}_{3}\right) .{ }^{14} \mathrm{~N}\left\{{ }^{1} \mathrm{H}\right\} \mathrm{NMR}$ (29 MHz): $\delta-21\left(\mathrm{NO}_{2}\right),-25 \mathrm{ppm}\left(\mathrm{NO}_{2}\right) . \mathrm{MS}\left(\mathrm{DCI}^{+}\right): \mathrm{m} / z(\%):$ $218.2(64)\left[\mathrm{M}+\mathrm{H}^{+}\right], 130.1(0.5)\left[\mathrm{C}_{2} \mathrm{H}_{3} \mathrm{~N}_{5} \mathrm{O}_{2}{ }^{+}\right], 89(26)\left[\mathrm{C}_{2} \mathrm{H}_{5} \mathrm{~N}_{2} \mathrm{O}_{2}{ }^{+}\right]$. Sensitivities (grain size: 100-500 $\mu \mathrm{m}$ ): IS: >40 J; FS: $252 \mathrm{~N}$; ESD: $0.6 \mathrm{~J}$.

5,5'-Bi(1-(2-nitrazapropan-1-yl)-3-nitro-1,2,4-triazole) 1-Chloro-2-nitrazapropane (186 mg, $1.49 \mathrm{mmol}$ ) was dissolved in acetone $(20 \mathrm{~mL})$ and dipotassium 3,3'-dinitro-5,5'-bi(1,2,4triazolate)dihydrate $(252 \mathrm{mg}, 0.75 \mathrm{mmol}$ ) was added. The reaction mixture was stirred overnight at ambient temperature. The precipitate was filtered off and the solvent was concentrated in vacuo. The crude product was washed with ethanol and water to afford beige 5 ( $86 \mathrm{mg}, 0.21 \mathrm{mmol}, 28 \%)$. DSC: $T_{\text {melt }}=225{ }^{\circ} \mathrm{C}$, $T_{\text {dec }}=228{ }^{\circ} \mathrm{C}$. EA $\left(\mathrm{C}_{8} \mathrm{H}_{10} \mathrm{~N}_{12} \mathrm{O}_{8}, 402.24 \mathrm{~g} \mathrm{~mol}^{-1}\right)$ : calcd C 23.89, H 2.51, N 41.29\%; found C 24.36, H 2.46, N 40.79\%. ${ }^{1} \mathrm{H}$ NMR (400 MHz): $\delta 6.84\left(\mathrm{~s}, 4 \mathrm{H}, \mathrm{CH}_{2}\right), 3.68 \mathrm{ppm}\left(\mathrm{s}, 6 \mathrm{H}, \mathrm{CH}_{3}\right) \cdot{ }^{13} \mathrm{C}\left\{{ }^{1} \mathrm{H}\right\}$ NMR (101 MHz): $\delta$ 143.7, $65.4\left(C_{2}\right), 39.1 \mathrm{ppm}\left(\mathrm{CH}_{3}\right) .{ }^{14} \mathrm{~N}\left\{{ }^{1} \mathrm{H}\right\}$ NMR (29 MHz): $\delta-26$ ppm $\left(\mathrm{NO}_{2}\right) . \mathrm{MS}\left(\mathrm{DCI}^{+}\right): \mathrm{m} / z$ (\%): 403.3 (45) $\left[\mathrm{M}+\mathrm{H}^{+}\right], 89.1(91)\left[\mathrm{C}_{2} \mathrm{H}_{5} \mathrm{~N}_{2} \mathrm{O}_{2}^{+}\right], 43.1(42)\left[\mathrm{C}_{2} \mathrm{H}_{5} \mathrm{~N}^{+}\right]$. Sensitivities (grain size: <100 $\mu \mathrm{m}$ ): IS: > 40 J; FS: $240 \mathrm{~N}$; ESD: $0.15 \mathrm{~J}$.

1-(2,4-Dinitroimidazol-1-yl)-2-nitrazapropane (6). To a solution of potassium 2,4-dinitroimidazolate $(530 \mathrm{mg}, 2.70 \mathrm{mmol})$ in acetone $(10 \mathrm{~mL})$ was added dropwise 1-chloro-2-nitrazapropane (333 $\mathrm{mg}, 2.67 \mathrm{mmol}$ ) in acetone $(1 \mathrm{~mL})$. The reaction mixture was stirred at $50{ }^{\circ} \mathrm{C}$ overnight and the formed precipitate was filtered off. The organic layer was concentrated in vacuo and the crude product was purified by washing with ethanol. The yellow solid was filtered off to afford $6(390 \mathrm{mg}, 1.58 \mathrm{mmol}, 59 \%)$. DSC: $T_{\text {melt }}=130{ }^{\circ} \mathrm{C}, T_{\text {dec }}=183{ }^{\circ} \mathrm{C} . \mathrm{EA}\left(\mathrm{C}_{5} \mathrm{H}_{6} \mathrm{~N}_{6} \mathrm{O}_{6}, 246.14 \mathrm{~g} \mathrm{~mol}^{-1}\right)$ : calcd C 24.40, H 2.46, N 34.14\%; found C 24.50, H 2.29, N 33.83\%. ${ }^{1} \mathrm{H}$ NMR (400 MHz): $\delta 8.70(\mathrm{~s}, 1 \mathrm{H}, \mathrm{CH}), 6.55(\mathrm{~s}, 2 \mathrm{H}$, $\mathrm{CH}_{2}$ ), $3.70 \mathrm{ppm}\left(\mathrm{s}, 3 \mathrm{H}, \mathrm{CH}_{3}\right) .{ }^{13} \mathrm{C}\left\{{ }^{1} \mathrm{H}\right\}$ NMR (101 MHz): $\delta 143.0$ (br, $\left.C \mathrm{NO}_{2}\right), 125.5(\mathrm{CH}), 65.3\left(\mathrm{CH}_{2}\right), 39.8 \mathrm{ppm}\left(\mathrm{CH}_{3}\right) .{ }^{14} \mathrm{~N}\left\{{ }^{1} \mathrm{H}\right\}$
NMR (29 MHz): $\delta-23\left(\mathrm{NO}_{2}\right),-30\left(\mathrm{NO}_{2}\right),-32\left(\mathrm{NO}_{2}\right),-210(\mathrm{br})$, -215 ppm (br). MS (DCI $\left.{ }^{+}\right): m / z(\%): 247$ (3) $\left[\mathrm{M}+\mathrm{H}^{+}\right]$. Sensitivities (grain size: <100 $\mu \mathrm{m}$ ): IS: $38 \mathrm{~J}$; FS: $120 \mathrm{~N}$; ESD: $0.13 \mathrm{~J}$.

1-(4,5-Dinitroimidazol-1-yl)-2-nitrazapropane (7). To a solution of 1-chloro-2-nitrazapropane (262 $\mathrm{mg}, 2.10 \mathrm{mmol}$ ) in acetonitrile $(15 \mathrm{~mL})$ was added potassium 4,5-dinitro-imidazolate $(412 \mathrm{mg}$, $2.10 \mathrm{mmol}$ ). The reaction mixture was stirred at $50{ }^{\circ} \mathrm{C}$ overnight and the precipitate was filtered off. The organic layer was removed in vacuo and the crude product was washed with ethanol. After drying in air, 7 (440 $\mathrm{mg}, 1.79 \mathrm{mmol}, 85 \%)$ was obtained as a colorless solid. DSC: $T_{\text {melt }}=142{ }^{\circ} \mathrm{C}, T_{\mathrm{dec}}=190{ }^{\circ} \mathrm{C}$. $\mathrm{EA}\left(\mathrm{C}_{5} \mathrm{H}_{6} \mathrm{~N}_{6} \mathrm{O}_{6}\right.$, $246.14 \mathrm{~g} \mathrm{~mol}^{-1}$ ): calcd C 24.40, H 2.46, N 34.14\%; found C 24.51, H 2.52, N 33.98\%. ${ }^{1} \mathrm{H}$ NMR (400 MHz): $\delta 8.28(\mathrm{~s}, 1 \mathrm{H}, \mathrm{CH}), 6.43$ (s, $2 \mathrm{H}, \mathrm{CH}_{2}$ ), $3.66 \mathrm{ppm}\left(\mathrm{s}, 3 \mathrm{H}, \mathrm{CH}_{3}\right) .{ }^{13} \mathrm{C}\left\{{ }^{1} \mathrm{H}\right\} \mathrm{NMR}(101 \mathrm{MHz})$ : $\delta 142.3\left(\mathrm{CNO}_{2}\right), 138.0(\mathrm{CH}), 129.6\left(\mathrm{CNO}_{2}\right), 62.9\left(\mathrm{CH}_{2}\right), 39.6 \mathrm{ppm}$ $\left(\mathrm{CH}_{3}\right) \cdot{ }^{14} \mathrm{~N}\left\{{ }^{1} \mathrm{H}\right\} \mathrm{NMR}(29 \mathrm{MHz}): \delta-24\left(\mathrm{NO}_{2}\right),-30\left(\mathrm{NO}_{2}\right),-34$ $\left(\mathrm{NO}_{2}\right),-135$ (br), -210 ppm (br). MS (DCI $\left.{ }^{+}\right): \mathrm{m} / \mathrm{z}$ (\%): 247 (11) $\left[\mathrm{M}+\mathrm{H}^{+}\right]$. Sensitivities: (grain size: $\left.100-500 \mu \mathrm{m}\right)$ : IS: $25 \mathrm{~J}$; FS: $144 \mathrm{~N}$; ESD: $0.15 \mathrm{~J}$.

1-(3,5-Dinitropyrazol-1-yl)-2-nitrazapropane (8). To a solution of 1-chloro-2-nitrazapropane $(124 \mathrm{mg}, 1.00 \mathrm{mmol})$ in acetone (5 mL) was added potassium 3,5-dinitropyrazolate $(195 \mathrm{mg}$, $1.00 \mathrm{mmol}$ ) and sodium bromide (192 $\mathrm{mg}, 0.99 \mathrm{mmol}$ ). The reaction mixture was stirred at ambient temperature for $14 \mathrm{~h}$ and the precipitate was filtered off. The organic layer was concentrated in vacuo and the crude product was washed with ethanol. The colorless precipitate was filtered off to yield 8 (139 mg, $0.57 \mathrm{mmol}, 57 \%$ ). DSC: $T_{\text {melt }}=126{ }^{\circ} \mathrm{C}, T_{\text {dec }}=210{ }^{\circ} \mathrm{C}$. EA $\left(\mathrm{C}_{5} \mathrm{H}_{6} \mathrm{~N}_{6} \mathrm{O}_{6}, 246.14 \mathrm{~g} \mathrm{~mol}^{-1}\right)$ : calcd C 24.40, H 2.46, N 34.14\%; found $\mathrm{C} 24.82, \mathrm{H} 2.41, \mathrm{~N} 33.75 \% .{ }^{1} \mathrm{H} \mathrm{NMR}(400 \mathrm{MHz}): \delta 7.91(\mathrm{~s}$, $1 \mathrm{H}, \mathrm{CH}), 6.72\left(\mathrm{~s}, 2 \mathrm{H}, \mathrm{CH}_{2}\right), 3.64 \mathrm{ppm}\left(\mathrm{s}, 3 \mathrm{H}, \mathrm{CH}_{3}\right) .{ }^{13} \mathrm{C}\left\{{ }^{1} \mathrm{H}\right\} \mathrm{NMR}$ (101 MHz): $\delta 154.1$ (br, $\mathrm{CNO}_{2}$ ), 147.7 (br, $\left.C \mathrm{NO}_{2}\right), 103.5(\mathrm{CH}), 67.9$ $\left(\mathrm{CH}_{2}\right), 39.9 \mathrm{ppm}\left(\mathrm{CH}_{3}\right) .{ }^{14} \mathrm{~N}\left\{{ }^{1} \mathrm{H}\right\} \mathrm{NMR}(29 \mathrm{MHz}): \delta-25\left(\mathrm{NO}_{2}\right)$, $-30\left(\mathrm{NO}_{2}\right),-178 \mathrm{ppm}(\mathrm{br})$. MS (DCI $\left.{ }^{+}\right): m / z(\%): 247$ (4) $\left[\mathrm{M}+\mathrm{H}^{+}\right]$, 200 (2) $\left[\mathrm{M}-\mathrm{NO}_{2}{ }^{+}\right]$. Sensitivities (grain size: $<100 \mu \mathrm{m}$ ): IS: $19 \mathrm{~J}$; FS: $288 \mathrm{~N}$; ESD: $0.10 \mathrm{~J}$.

1-(3,4-Dinitropyrazol-1-yl)-2-nitrazapropane (9). To a suspension of potassium 3,4-dinitropyrazolate $(1.00 \mathrm{~g}, 4.31 \mathrm{mmol})$ and sodium bromide (0.44 g, $4.31 \mathrm{mmol}$ ) in acetonitrile was added 1-chloro-2nitrazapropane $(0.54 \mathrm{~g}, 4.31 \mathrm{mmol})$ dissolved in acetonitrile. After two days of stirring at ambient temperature, the inorganic solid was filtered off. The organic layer was concentrated in vacuo and purified via column chromatography (silica gel, ethyl acetate/ i-hexane $(70: 30))$. Due to decomposition by chromatography, only a small amount of colorless 9 (36 mg, $0.15 \mathrm{mmol}, 3 \%$ ) was obtained. DSC: $T_{\text {melt }}=82{ }^{\circ} \mathrm{C}, T_{\text {dec }}=234{ }^{\circ} \mathrm{C}$. EA $\left(\mathrm{C}_{5} \mathrm{H}_{6} \mathrm{~N}_{6} \mathrm{O}_{6}\right.$, $\left.246.14 \mathrm{~g} \mathrm{~mol}^{-1}\right)$ : calcd C 24.40, H 2.46, N 34.14\%; found C 22.72, H 2.15, N 31.07\%. ${ }^{1} \mathrm{H}$ NMR (400 MHz): $\delta 9.03$ (s, 1H, CH), 6.33 (s, $2 \mathrm{H}, \mathrm{CH}_{2}$ ), $3.63 \mathrm{ppm}\left(\mathrm{s}, 3 \mathrm{H}, \mathrm{CH}_{3}\right) .{ }^{13} \mathrm{C}\left\{{ }^{1} \mathrm{H}\right\}$ NMR (101 MHz): $\delta 148.4\left(\mathrm{br}, \mathrm{CNO}_{2}\right), 134.0(\mathrm{CH}), 126.9\left(\mathrm{br}, \mathrm{CNO}_{2}\right), 66.9\left(\mathrm{CH}_{2}\right), 38.8$ ppm $\left(\mathrm{CH}_{3}\right) \cdot{ }^{14} \mathrm{~N}\left\{{ }^{1} \mathrm{H}\right\}$ NMR $(29 \mathrm{MHz}): \delta-28\left(\mathrm{NO}_{2}\right),-31\left(\mathrm{NO}_{2}\right)$, -176 ppm (br). MS (DCI $\left.{ }^{+}\right): m / z$ (\%): 247 (73) [M+ H $\left.{ }^{+}\right], 200$ (26) $\left[\mathrm{M}^{+}-\mathrm{NO}_{2}\right]$. Sensitivities (grain size: $<100 \mu \mathrm{m}$ ): IS: $>40 \mathrm{~J} . R_{\mathrm{f}}$ value (silica gel, ethylacetate/i-hexane (70:30)): 0.72 .

1-(3,4,4'-Trinitro-1,3' $\mathbf{3}^{\prime}$-bipyrazol-2'-yl)-2-nitrazapropane (10). 10 was obtained as a side product by the synthesis of 9 . 
Isolation by column chromatography (silica gel, ethyl acetate/ i-hexane (70:30)) yielded 10 (103 $\mathrm{mg}, 0.29 \mathrm{mmol}, 14 \%)$ as a rose solid. DSC: $T_{\text {melt }}=133{ }^{\circ} \mathrm{C}, T_{\text {dec }}=264{ }^{\circ} \mathrm{C}$. $\mathrm{EA}\left(\mathrm{C}_{8} \mathrm{H}_{7} \mathrm{~N}_{9} \mathrm{O}_{8}, 357.20 \mathrm{~g}\right.$ $\mathrm{mol}^{-1}$ ): calcd C 26.90, H 1.98, N 38.83\%; found C 26.84, H 1.87, N 34.48\%. ${ }^{1} \mathrm{H}$ NMR (400 MHz): $\delta 9.50(\mathrm{~s}, 1 \mathrm{H}, \mathrm{CH}), 8.56(\mathrm{~s}, 1 \mathrm{H}$, $\mathrm{CH}), 6.33$ (s, 2H, $\left.\mathrm{CH}_{2}\right), 3.59 \mathrm{ppm}\left(\mathrm{s}, 3 \mathrm{H}, \mathrm{CH}_{3}\right) .{ }^{13} \mathrm{C}\left\{{ }^{1} \mathrm{H}\right\}$ NMR (101 $\mathrm{MHz}): \delta 150.1$ (br, $\left.\mathrm{CNO}_{2}\right), 138.2(\mathrm{CH}), 137.0(\mathrm{CH}), 132.0\left(C_{\mathrm{q}}\right)$, 129.7 (br, $\left.\mathrm{CNO}_{2}\right), 128.2$ (br, $\left.C \mathrm{NO}_{2}\right), 63.9\left(\mathrm{CH}_{2}\right), 39.0 \mathrm{ppm}\left(\mathrm{CH}_{3}\right)$. ${ }^{14} \mathrm{~N}\left\{{ }^{1} \mathrm{H}\right\} \mathrm{NMR}(29 \mathrm{MHz}): \delta-20\left(\mathrm{NO}_{2}\right),-25\left(\mathrm{NO}_{2}\right),-26\left(\mathrm{NO}_{2}\right)$, -170 ppm (br). MS (DCI $\left.{ }^{+}\right): m / z(\%): 358(4)\left[\mathrm{M}+\mathrm{H}^{+}\right]$. Sensitivities (grain size: <100 $\mu \mathrm{m}$ ): IS: > $40 \mathrm{~J}$; FS: $288 \mathrm{~N}$; ESD: $0.20 \mathrm{~J} . R_{\mathrm{f}}$ value (silica gel, ethyl acetate/i-hexane (70:30)): 0.83 .

1-(5-Chloro-3,4-dinitropyrazol-1-yl)-2-nitrazapropane (11). To a mixture of potassium 3,4,5-trinitropyrazolate semihydrate $(575 \mathrm{mg}$, $2.30 \mathrm{mmol}$ ) in acetonitrile was added 1-chloro-2-nitrazapropane (286 mg, $2.30 \mathrm{mmol}$ ) dissolved in acetonitrile $(5 \mathrm{~mL})$. The reaction mixture was stirred under reflux for 2 days and the precipitate was filtered off. The organic layer was concentrated in vacuo and the crude oily product was dissolved in hot dichloromethane. The precipitate was filtered off and the filtrate was removed in vacuo. The resulting oil was overlaid with methanol and the formed precipitate was filtered off and dried in air to afford $11(116 \mathrm{mg}$, $0.41 \mathrm{mmol}, 18 \%)$. DSC: $T_{\text {melt }}=82{ }^{\circ} \mathrm{C}, T_{\text {dec }}=214{ }^{\circ} \mathrm{C}$. EA $\left(\mathrm{C}_{5} \mathrm{H}_{5} \mathrm{ClN}_{6} \mathrm{O}_{6}, 280.58 \mathrm{~g} \mathrm{~mol}^{-1}\right)$ : calcd C 21.40, H 1.80, N 29.95, Cl 12.64\%; found C 21.71, H 1.78, N 29.78, Cl 12.77\%. ${ }^{1} \mathrm{H}$ NMR (400 MHz): $\delta 6.42\left(\mathrm{~s}, 2 \mathrm{H}, \mathrm{CH}_{2}\right), 3.66 \mathrm{ppm}\left(\mathrm{s}, 3 \mathrm{H}, \mathrm{CH}_{3}\right) .{ }^{13} \mathrm{C}\left\{{ }^{1} \mathrm{H}\right\}$ NMR (101 MHz): $\delta 148.4$ (br, $C \mathrm{NO}_{2}$ ), $130.0(C \mathrm{Cl}), 123.9$ (br, $\left.\mathrm{CNO}_{2}\right), 64.4\left(\mathrm{CH}_{2}\right), 39.0 \mathrm{ppm}\left(\mathrm{CH}_{3}\right) .{ }^{14} \mathrm{~N}\left\{{ }^{1} \mathrm{H}\right\}$ NMR $(29 \mathrm{MHz})$ : $\delta-28\left(\mathrm{NO}_{2}\right),-31\left(\mathrm{NO}_{2}\right),-176 \mathrm{ppm}(\mathrm{br}) . \mathrm{MS}\left(\mathrm{DCI}^{+}\right): \mathrm{m} / z(\%):$ $281(38)\left[\mathrm{M}+\mathrm{H}^{+}\right], 234(3)\left[\mathrm{M}^{+}-\mathrm{NO}_{2}\right]$. Sensitivities (grain size: $<100 \mu \mathrm{m})$ : IS: > 40 J; FS: 288 N; ESD: $0.10 \mathrm{~J}$.

1-(4-Amino-3,5-dinitropyrazol-1-yl)-2-nitrazapropane 1-Chloro-2-nitrazapropane (115 mg, $0.92 \mathrm{mmol}$ ) was dissolved in acetone $(15 \mathrm{~mL})$, and potassium 4-amino-3,5-dinitropyrazolate semihydrate (187 $\mathrm{mg}, 0.85 \mathrm{mmol}$ ) was added. The reaction mixture was stirred overnight at ambient temperature. The precipitate was filtered off and the organic layer was concentrated in vacuo. The crude product was washed with ethanol and diethyl ether to afford 12 (197 mg, $0.75 \mathrm{mmol}, 88 \%$ ) as a yellow solid. DSC: $T_{\text {melt }}=141{ }^{\circ} \mathrm{C}$, $T_{\text {dec }}=165{ }^{\circ} \mathrm{C}$. EA $\left(\mathrm{C}_{5} \mathrm{H}_{7} \mathrm{~N}_{7} \mathrm{O}_{6}, 261.15 \mathrm{~g} \mathrm{~mol}^{-1}\right)$ : calcd C 23.00, H 2.70, N 37.54\%; found C 23.19, H 2.65, N 37.25\%. ${ }^{1} \mathrm{H}$ NMR (400 MHz): $\delta 7.01\left(\mathrm{~s}, 2 \mathrm{H}, \mathrm{NH}_{2}\right), 6.66\left(\mathrm{~s}, 2 \mathrm{H}, \mathrm{CH}_{2}\right), 3.61 \mathrm{ppm}$ (s, 3H, CH $\left.H_{3}\right) \cdot{ }^{13} \mathrm{C}\left\{{ }^{1} \mathrm{H}\right\}$ NMR (101 MHz): $\delta$ 130.5-130.4 (3C, $\mathrm{CNH}_{2}$, $\left.\mathrm{CNO}_{2}\right), 67.3\left(\mathrm{CH}_{2}\right), 38.8 \mathrm{ppm}\left(\mathrm{CH}_{3}\right) .{ }^{14} \mathrm{~N}\left\{{ }^{1} \mathrm{H}\right\}$ NMR $(29 \mathrm{MHz})$ : $\delta-19\left(\mathrm{NO}_{2}\right),-23\left(\mathrm{NO}_{2}\right),-26\left(\mathrm{NO}_{2}\right),-184(\mathrm{br}),-318 \mathrm{ppm}(\mathrm{br}) . \mathrm{MS}$ $\left(\mathrm{DEI}^{+}\right): m / z$ (\%): $261(8)\left[\mathrm{M}^{+}\right]$. Sensitivities (grain size: $<100 \mu \mathrm{m}$ ): IS: $>40$ J; FS: $>360 \mathrm{~N}$; ESD: $0.4 \mathrm{~J}$.

\section{Acknowledgements}

The Konrad Adenauer Foundation is gratefully acknowledged for the award of a PhD scholarship to C. P. Financial support for this work by the Ludwig-Maximilian University of Munich (LMU), the U.S. Army Research Laboratory (ARL), the Office of Naval Research (ONR) under grant no. ONR.N00014-16-1-2062, and the Bundeswehr - Wehrtechnische Dienststelle für Waffen und Munition (WTD 91) under grant no. E/E91S/FC015/CF049 is gratefully acknowledged. The authors acknowledge collaborations with Dr Mila Krupka (OZM Research, Czech Republic) in the development of new testing and evaluation methods for energetic materials and with Dr Muhamed Sućeska (Brodarski Institute, Croatia) in the development of new computational codes to predict the detonation and propulsion parameters of novel explosives. We are indebted to and thank Drs Betsy M. Rice, Jesse Sabatini and Brad Forch (ARL, Aberdeen, Proving Ground, MD) for many inspired discussions. The authors would also like to thank Stefan Huber for assistance during the sensitivity measurements.

\section{Notes and references}

1 P. Ravi, D. M. Badgujar, G. M. Gore, S. P. Tewari and A. K. Sikder, Propellants, Explos., Pyrotech., 2011, 36, 393-403.

2 D. W. Doll, J. M. Hanks, T. K. Highsmith and G. K. Lund, WO01/46092A1, 2001.

3 (a) R. Damavarapu, N. Gelber, R. Surapaneni, M. Zhang, R. Duddu and D. Parithosh, New Trends Res. Energ. Mater., Proc. Semin., 12th, Pardubice (Czech Republic), 2009, pp. 109-114; (b) J. R. Cho, K. J. Kim, S. G. Cho and J. K. Kim, J. Heterocycl. Chem., 2002, 39, 141-147.

4 (a) G. Hervé, C. Roussel and H. Graindorge, Angew. Chem., Int. Ed., 2010, 49, 3177-3181 (Angew. Chem., 2010, 122, 3245-3249); (b) I. L. Dalinger, I. A. Vatsadze, T. K. Shkineva, G. P. Popova, S. A. Shevelev and Y. V. Nelyubina, J. Heterocycl. Chem., 2013, 50, 911-924.

5 S. Ek, K. Dudek, J. Johansson and N. Latypov, New Trends Res. Energ. Mater., Proc. Semin., 17th, Pardubice (Czech Republic), 2014, pp. 180-188.

6 M.-H. V. Huynh, M. A. Hiskey, E. L. Hartline, D. P. Montoya and R. Gilardi, Angew. Chem., Int. Ed., 2004, 43, 4924-4928 (Angew. Chem., 2004, 116, 5032-5036).

7 (a) L. I. Bagal, M. S. Pevzner, A. N. Frolov and N. I. Sheludyakova, Khim. Geterotsikl. Soedin., 1970, 259-264; (b) P. F. Pagoria, G. S. Lee, A. R. Mitchell and R. D. Schmidt, Thermochim. Acta, 2002, 384, 187-204; (c) T. M. Klapötke, A. Penger, C. Pflüger, J. Stierstorfer and M. Sućeska, Eur. J. Inorg. Chem., 2013, 4667-4678; (d) M. A. Kettner and T. M. Klapötke, Chem. - Eur. J., 2015, 21, 3755-3765; (e) Y. Tang, C. He, H. Gao and J. M. Shreeve, J. Mater. Chem. A, 2015, 3, 15576-15582; $(f)$ P. Yin, J. Zhang, D. A. Parrish and J. M. Shreeve, Chem. - Eur. J., 2014, 20, 16529-16536; (g) P. Yin, D. A. Parrish and J. M. Shreeve, Angew. Chem., Int. Ed., 2014, 53, 12889-12892 (Angew. Chem., 2014, 126, 13103-13106); (h) O. P. Shitov, V. L. Korolev, V. S. Bogdanov and V. A. Tartakovsky, Russ. Chem. Bull., 2003, 52, 695-699; (i) J. Zhang, C. He, D. A. Parrish and J. M. Shreeve, Chem. Eur. J., 2013, 19, 8929-8936.

8 (a) G. L. Starova, O. V. Frank-Kamenetskaya and M. S. Pevzner, J. Struct. Chem., 1989, 29, 799-801; (b) Y.-X. Li, X.-J. Wang and J.-L. Wang, Acta Crystallogr., Sect. E: Struct. Rep. Online, 2009, 65, 03073 . 
9 (a) T. M. Klapötke, A. Penger and C. Pflüger, in New Trends Res. Energ. Mater., Proc. Semin., 14th, Pardubice (Czech Republic), 2011, pp. 753-761; (b) A. Penger, Offenkettige Nitramine als potentielle Ersatzstoffe für Cyclomethylentrinitramin (RDX), $\mathrm{PhD}$ thesis, Ludwig Maximilian University of Munich, 2011.

10 (a) J. C. Bottaro, R. J. Schmitt, A. M. Petrie and P. E. Penwell, US62555112, 2001; (b) T. K. Highsmith, J. M. Hanks, S. P. Velarde and J. C. Bottaro, WO2002060881A1, 2002.

11 N. Fischer, K. Karaghiosoff, T. M. Klapötke and J. Stierstorfer, Z. Anorg. Allg. Chem., 2010, 636, 735-749.

12 (a) K. Y. Lee, C. B. Storm, M. A. Hiskey and M. D. Coburn, J. Energ. Mater., 1991, 9, 415-428; (b) R. D. Schmidt, G. S. Lee, P. F. Pagoria, A. R. Mitchell and R. Gilardi, J. Heterocycl. Chem., 2001, 38, 1227-1230; (c) A. R. Katritzky, S. Singh, K. Kirichenko, M. Smiglak, J. D. Holbrey, W. M. Reichert, S. K. Spear and R. D. Rogers, Chem. - Eur. J., 2006, 12, 4630-4641; (d) G. Wuellner, F.-W. Herkenrath, A. Juelich, Y. Yamada and S. Kawabe, WO2010021409, 2010; (e) R. Hüttel and F. Büchele, Chem. Ber., 1955, 88, 1586-1590; $(f)$ J. W. A. M. Janssen, H. J. Koeners, C. G. Kruse and C. L. Habraken, J. Org. Chem., 1973, 38, 1777-1782; (g) G. T. Morgan and I. Ackerman, J. Chem. Soc., Trans., 1923, 123, 1308-1318; (h) Y. V. Serov, M. S. Pevzner, T. P. Kofman and I. V. Tselinskii, Russ. J. Org. Chem., 1990, 26, 773-777; ( $i$ ) L. I. Bagal, M. S. Pevzner, A. N. Frolov and N. I. Sheludyakova, Chem. Heterocycl. Compd., 1970, 6, 240-244; (j) A. A. Dippold, T. M. Klapötke and N. Winter, Eur. J. Inorg. Chem., 2012, 3474-3484; ( $k$ ) K.-Y. Lee, L. B. Chapman and M. D. Cobura, J. Energ. Mater., 1987, 5, 27-33.

13 (a) L. I. Bagal, M. S. Pevzner, V. Y. Samarenko and A. P. Egorov, Khim. Geterotsikl. Soedin., 1970, 1701-1703; (b) M. S. Pevzner, V. Y. Samarenko and L. I. Bagal, Khim. Geterotsikl. Soedin., 1972, 117-119; (c) T. P. Kofman, G. Y. Kartseva, V. I. Namestnikov and E. A. Paketina, Russ. J. Org. Chem., 1998, 34, 1032-1039; (d) M. S. Pevzner, T. P. Kofman, E. N. Kibasova, L. F. Sushchenko and T. L. Uspenskaya, Khim. Geterotsikl. Soedin., 1980, 257-261; (e) T. P. Kofman, Russ. J. Org. Chem., 2001, 37, 1158-1168.

14 I. L. Dalinger, I. A. Vatsadze, T. K. Shkineva, I. O. Kortusov, G. P. Popova, V. V. Kachala and S. A. Sheveleva, Russ. Chem. Bull., 2010, 59, 1786-1790.

15 I. J. Ferguson, K. Schofield, J. W. Barnett and M. R. Grimmett, J. Chem. Soc., Perkin Trans. 1, 1977, 672-675.

16 P. Cohen-Fernandes, C. Erkelens, C. G. M. Van Eendenburg, J. J. Verhoeven and C. L. Habraken, J. Org. Chem., 1979, 44, 4156-4160.

17 I. L. Dalinger, I. A. Vatsadze, T. K. Shkineva, G. P. Popova and S. A. Shevelev, Mendeleev Commun., 2011, 21, 149-150.

18 M. Hesse, H. Meier and B. Zeeh, Spektroskopische Methoden in der organischen Chemie, Thieme, Stuttgart, 7 edn, 2005.

19 (a) I. J. Solomon, R. K. Momii, F. H. Jarke, A. J. Kacmarek, J. K. Raney and P. C. Adlaf, J. Chem. Eng. Data, 1973, 18, 335-337; (b) A. R. Farminer and G. A. Webb, Tetrahedron, 1975, 31, 1521-1526.

20 F. H. Allen, O. Kennard, D. G. Watson, L. Brammer, A. G. Orpen and R. Taylor, J. Chem. Soc., Perkin Trans. 2, 1987, S1-S19.
21 N. B. Bolotina, E. Zhurova and A. A. Pinkerton, J. Appl. Crystallogr., 2003, 36, 280-285.

22 A. Bondi, J. Phys. Chem., 1964, 68, 441-451.

23 B. Aas, M. A. Kettner, T. M. Klapötke, M. Sućeska and C. Zoller, Eur. J. Inorg. Chem., 2013, 6028-6036.

24 (a) Test Methods According to the UN Manual of Test and Criteria, Recommendations on the Transport of Dangerous Goods, United Nations Publication, New York, Geneva, 4th revised edn, 2003: impact: insensitive $>40 \mathrm{~J}$, less sensitive $\geq 35 \mathrm{~J}$, sensitive $\geq 4 \mathrm{~J}$, very sensitive $\leq 3 \mathrm{~J}$; friction: insensitive $>360 \mathrm{~N}$, less sensitive $=360 \mathrm{~N}$, sensitive $<360 \mathrm{~N}$ to $>80 \mathrm{~N}$, very sensitive $\leq 80 \mathrm{~N}$, extremely sensitive $\leq 10 \mathrm{~N}$; $(b)$ NATO, Standardization Agreement 4489 (STANAG 4489), Explosives, Impact Sensitivity Tests 1999; (c) NATO, Standardization Agreement 4487 (STANAG 4487), Explosives, Friction Sensitivity Tests 2002.

25 T. M. Klapötke, Chemistry of High-Energy Materials, De Gruyter, Berlin, Bosten, 2015.

26 M. Sućeska, Explo5 program, Zagreb, Croatia, 6.02 edn, 2014.

27 (a) J. J. A. Montgomery, M. J. Frisch, J. W. Ochterski and G. A. Petersson, J. Chem. Phys., 2000, 112, 6532-6542; (b) J. W. Ochterski, G. A. Petersson and J. J. A. Montgomery, J. Chem. Phys., 1996, 104, 2598-2619.

28 M. J. Frisch, G. W. Trucks, H. B. Schlegel, G. E. Scuseria, M. A. Robb, J. R. Cheeseman, G. Scalmani, V. Barone, B. Mennucci, G. A. Petersson, H. Nakatsuji, M. Caricato, X. Li, H. P. Hratchian, A. F. Izmaylov, J. Bloino, G. Zheng, J. L. Sonnenberg, M. Hada, M. Ehara, K. Toyota, R. Fukuda, J. Hasegawa, M. Ishida, T. Nakajima, Y. Honda, O. Kitao, H. Nakai, T. Vreven, J. J. A. Montgomery, J. E. Peralta, F. Ogliaro, M. Bearpark, J. J. Heyd, E. Brothers, K. N. Kudin, V. N. Staroverov, R. Kobayashi, J. Normand, K. Raghavachari, A. Rendell, J. C. Burant, S. S. Iyengar, J. Tomasi, M. Cossi, N. Rega, J. M. Millam, M. Klene, J. E. Knox, J. B. Cross, V. Bakken, C. Adamo, J. Jaramillo, R. Gomperts, R. E. Stratmann, O. Yazyev, A. J. Austin, R. Cammi, C. Pomelli, J. W. Ochterski, R. L. Martin, K. Morokuma, V. G. Zakrzewski, G. A. Voth, P. Salvador, J. J. Dannenberg, S. Dapprich, A. D. Daniels, O. Farkas, J. B. Foresman, J. V. Ortiz, J. Cioslowski and D. J. Fox, Gaussian 09, Revision A.02, Gaussian Inc., Wallingford, CT, 2009.

29 (a) M. S. Westwell, M. S. Searle, D. J. Wales and D. H. Williams, J. Am. Chem. Soc., 1995, 117, 5013-5015; (b) F. Trouton, Philos. Mag., 1884, 18, 54-57.

30 C. Xue, J. Sun, B. Kang, Y. Liu, X. Liu, G. Song and Q. Xue, Propellants, Explos., Pyrotech., 2010, 35, 333-338.

31 CrysAlisPro, Version 1.171.35.11 (release 16.05.2011 CrysAlis171.net), Agilent Technologies, 2011.

32 L. J. Farrugia, J. Appl. Crystallogr., 1999, 32, 837-838.

33 A. L. Spek, Platon, A Multipurpose Crystallographic Tool, Utrecht University, Utrecht, NL, 1997.

34 (a) M. Sućeska, Propellants, Explos., Pyrotech., 1991, 16, 197-202; (b) M. Sućeska, Propellants, Explos., Pyrotech., 1999, 24, 280-285. 